\title{
THE ROLE OF B ACTERIAL STIMULI IN INFLAMMATION-DRIVEN BONE FORMATION
}

\author{
M. Croes ${ }^{1}$, M.C. Kruyt ${ }^{1}$, W. Boot ${ }^{1}$, B. Pouran ${ }^{1,2}$, M.V.J. Braham ${ }^{1}$, S.A. Pakpahan ${ }^{1}$, H. Weinans ${ }^{1,2,3}$, \\ H.C. Vogely ${ }^{1}$, A.C. Fluit ${ }^{4}$, W.J.A. Dhert ${ }^{1,5}$, J. Alblas ${ }^{1 *}$ and F.C. Öner ${ }^{1}$ \\ ${ }^{1}$ Department of Orthopaedics, University Medical Centre Utrecht, Utrecht, the Netherlands \\ ${ }^{2}$ Department of Biomechanical Engineering, Delft University of Technology, Delft, the Netherlands \\ ${ }^{3}$ Department of Rheumatology, University Medical Centre Utrecht, Utrecht, the Netherlands \\ ${ }^{4}$ Department of Medical Microbiology, University Medical Centre Utrecht, Utrecht, the Netherlands \\ ${ }^{5}$ Faculty of Veterinary Medicine, Utrecht University, Utrecht, the Netherlands
}

\begin{abstract}
Immune cells and their soluble factors regulate skeletal cells during normal bone regeneration and pathological bone formation. Bacterial infections can trigger immune responses that activate pro-osteogenic pathways, but these are usually overshadowed by osteolysis and concerns of systemic inflammation. The aim of this study was to determine whether the transient local inflammatory reaction to non-viable bacterial immune agonists could lead to favourable new bone formation. In a series of rabbit studies, as proof-of-concept, it was determined how tibial intramedullary injection of viable or killed bacterial species affected bone remodelling and new bone formation. Application of killed bacteria led to considerable new bone formation after 4 weeks, without the prolonged systemic inflammation and exaggerated bone lysis seen with active infection. The osteo-immunomodulatory effects of various species of killed bacteria and the dose response relationship were subsequently screened in ectopically-implanted ceramic scaffolds. Histomorphometry after 8 weeks showed that a relatively low dose of killed bacteria enhanced ectopic bone induction. Moreover, lipoteichoic acid the bacterial cell-wall derived toll-like-receptor (TLR)-2 activator - was identified as an osteo-stimulatory factor. Collectively, the data indicated that bacterial stimuli could be harnessed to stimulate osteogenesis, which occurs through a synergy with osteoinductive signals. This finding holds promise for the use of nonviable bacteria, bacterial antigens, or their simplified analogues as immuno-modulatory bone regenerating tools in bone biomaterials.
\end{abstract}

Keywords: osteoimmunology, osteomyelitis, stromal/stem cells, osteoblasts, BMPs/TGF-beta, toll-likereceptors.

*Address for correspondence: Jacqueline Alblas, $\mathrm{PhD}$, Department of Orthopaedics University Medical Centre Utrecht, Rm G05.228, P.O. Box 85500, Utrecht 3508 GA, the Netherlands Telephone: +31 (0)88 7550294 Fax: +31 (0)30 2510638 Email: j.alblas@umcutrecht.nl

Copyright policy: This article is distributed in accordance with Creative Commons Attribution Licence (http://creativecommons.org/licenses/by-sa/4.0/).

\section{Introduction}

Transplantation of autologous bone is the gold standard for the repair of critical bone defects; however, its limited availability and the increased surgery time are major drawbacks (Marchand et al., 2017; Simmonds et al., 2013). Materials that mimic the inorganic phase and architecture of bone, such as porous calcium phosphates $(\mathrm{CaP})$, are available as off-the-shelf bone substitutes, but are still clinically inferior to autologous bone (Campana et al., 2014; Kadam et al., 2016). To further improve CaP products, cell- or growth factor-based treatments have been extensively investigated (Gothard et al., 2014; Ma et al., 2014). However, to date, clinical translation of such approaches has been hampered due to lack of efficacy and high costs (Tatara and Mikos, 2016). To better recapitulate the normal biology of bone healing, immune modulating drugs or cytokines are increasingly being studied as bone-promoting mediators (Croes et al., 2017b; Croes et al., 2018; Chen et al., 2016). In this regard, there is growing evidence that the immuno-modulatory properties of biomaterials govern the subsequent stages of bone formation (Chen et al., 2016; Davison et al., 2014; Fellah et al., 2010). 
Pathologic conditions involving excessive bone formation can serve as models to identify osteoimmunomodulatory factors. Although bacterial infections induce inflammatory responses that mostly have detrimental effects on bone formation due to uncontrolled receptor activator of nuclear factor kappa-B ligand (RANKL) and pro-inflammatory cytokine-induced osteoclast formation (Lew and Waldvogel, 2004; Marriott, 2013; Tatara and Mikos, 2016), bacterial infections are also associated with periosteal bone formation or heterotopic ossifications via yet unknown pathways (Cassat et al., 2013; Pavey et al., 2015). The profound effects of bacterial infections on bone suggest that bacteria-induced inflammatory cues can harbour bone-promoting effects under appropriate conditions, which could potentially be harnessed for advanced bone biomaterials production. This hypothesis is supported by the observation that, in general, a balanced inflammatory response coordinates osteogenic and angiogenic processes during bone healing (Schmidt-Bleek et al., 2015), while several other pathological conditions are also known to activate inflammatory pathways leading to osteogenesis (Maksymowych, 2010; Peterson et al., 2014).

The current authors previously demonstrated that a localised infection with Gram-positive Staphylococcus aureus (SA) leads to a combination of osteolysis and significant osteogenesis in a rabbit tibia implantation model (Croes et al., 2017a). To narrow down the pro-osteogenic immune agonists, a first step is to determine whether inflammation-induced osteogenesis is a general phenomenon also seen for other bacterial genera. For example, Escherichia sp. or Bacillus sp. are commonly associated with human infection and, according to their Gram classification, they have distinct cell wall immune agonists (e.g. thickness of the peptidoglycan layer and presence of teichoic acids, lipoproteins and lipopolysaccharides) that could differently affect the osteogenic response (Fiedler et al., 2013). The reported causal relationship between selective bacterial species and new bone formation also requires more investigation. This has been speculated for cochlear ossifications, following Haemophilus influenzae meningitis, as well as in pulmonary tuberculosis lung ossifications (CayeThomasen and Tos, 2000; Chan et al., 2002).

Clearly, the use of virulent bacteria as bonestimulating agents has little therapeutic merit due to their uncontrolled proliferation, unpredictable systemic effects, and/or the severe osteolysis they can cause (Bilgili et al., 2015; Kim et al., 2013; Nair et al., 1996). Alternatively, their non-viable counterparts or downstream secreted cytokines may be harnessed as safer alternatives for new bone formation. Modified bacterial antigens or synthetic mimics, with improved safety profiles, are already used as pro-inflammatory adjuvants in vaccines or cancer therapies (Engel et al., 2011; Steinhagen et al., 2011). Of these, toll-likereceptor (TLR) agonists, of which the natural forms are mainly derived from the bacterial cell wall (Elson et al., 2007; Kieser and Kagan, 2017), activate several immune cell subsets and could be readily applied in strategies to enhance bone regeneration. For example, lipoteichoic acid (LTA) is a TLR-2 agonist found on $S$. aureus, and induces several cytokines (e.g. TNF- $\alpha$ and IL-6) (Finney et al., 2012; Kimbrell et al., 2008) involved in bone healing (Gerstenfeld et al., 2003; Yang et al., 2007). Since previous reports have been inconclusive on its osteo-immunomodulatory effects (Croes et al., 2017b; Fiedler et al., 2013), it remains to be determined whether LTA can stimulate osteogenesis.

In the current series of rabbit experiments, the potential of applying bacteria-derived immune agonists to enhance bone formation was explored. A tibia medullary inoculation model was used as proof-of-concept to characterise orthotopic new bone formation and remodelling in response to septic and aseptic inflammation. This model was previously found to be suitable to identify proinflammatory bone-promoting mediators (Croes et al., 2017a). To elucidate if pro-osteogenic stimuli are only induced by viable $S$. aureus species, killed bacterial species with different Gram status were also explored. Furthermore, an ectopic bone induction model was used to screen the potential of multiple non-viable bacterial immune agonists, the effect of bacterial killing methods, and their dose response relationship. In the ectopic model, it can furthermore be investigated whether functionalisation of bone scaffolds with bacteria-derived immune agonists leads to superior bone-inductive properties.

\section{Materials and Methods}

\section{Study design}

A rabbit tibia inoculation model was used to study inflammation-enhanced bone formation (Croes et al., 2017a). It was shown previously, in this model, that periprosthetic $S$. aureus (SA) infections generated quantifiable new bone formation. In the current study, viable bacteria were therefore used again as a control group for non-viable conditions. In the tibia model, the untreated contralateral limb served as a within-subject control, as the implant alone was not found to cause any bone change (Croes et al., 2017a). Bone remodelling and new bone formation were studied after 4 and 8 weeks by $\mu \mathrm{CT}$, histology, and determination of fluorochrome label incorporation. Systemic inflammation was measured in blood samples on days 3, 7, 14 and 28.

In a first study (Viable/killed S. aureus study, Table 1), the relevance of the intramedullary titanium implant was determined by comparing SA delivery with (SA + Ti) and without (SA) implant. Furthermore, it was examined whether gamma irradiation-killed ( $\gamma$ i) SA could elicit an adequate inflammatory response and enhanced bone formation. A high dose of $\gamma \mathrm{i}$ SA was studied in combination with a metal implant ( $\gamma \mathrm{i} \mathrm{SA}+\mathrm{Ti})$ to compare as closely as possible with the peri-prosthetic infection group. In a second 
Table 1. Groups included in the viable/killed S. aureus study. A total of 20 rabbits received unilateral treatment in the tibia. $\gamma \mathrm{i}$ : gamma irradiation-killed.

\begin{tabular}{|c|c|c|c|}
\hline Group & Bacterial stimulus & Dose & Animals \\
\hline SA & S. aureus & $5 \times 10^{5}$ & 6 \\
\hline $\mathrm{SA}+\mathrm{Ti}$ & S. aureus & $5 \times 10^{5}$ & 6 \\
\hline$\gamma \mathbf{i} \mathbf{S A}+\mathbf{T i}$ & yi S. aureus & $1 \times 10^{9}$ & 8 \\
\hline
\end{tabular}

Table 2. Groups included in the bacterial comparison study. A total of 20 rabbits received unilateral treatment in the tibia combined with subcutaneous/intramuscular scaffolds. $\gamma$ i: gamma irradiation-killed, BMP-2: bone morphogenetic protein 2.

\begin{tabular}{|c|c|c|c|c|}
\hline \multicolumn{5}{|c|}{ Tibia inoculation model } \\
\hline Group & Bacterial stimulus & Dose & \multicolumn{2}{|c|}{ \#Animals } \\
\hline$\gamma$ i SA & $\gamma \mathrm{i}$ S. aureus & $1 \times 10^{9}$ & \multicolumn{2}{|c|}{6} \\
\hline$\gamma$ i EC & $\gamma \mathrm{i}$ E. coli & $1 \times 10^{9}$ & \multicolumn{2}{|c|}{7} \\
\hline$\gamma \mathbf{i} \mathbf{M M}$ & $\gamma$ i M. marinum & $1 \times 10^{9}$ & \multicolumn{2}{|c|}{7} \\
\hline \multicolumn{5}{|c|}{ Subcutaneous osteoinduction model } \\
\hline \multirow[b]{2}{*}{ Group } & \multirow[b]{2}{*}{ Bacterial stimulus } & \multicolumn{2}{|c|}{ Concentration $(/ \mathrm{mL})$} & \multirow[b]{2}{*}{ \# Scaffolds } \\
\hline & & Bacterial stimulus & BMP-2 & \\
\hline Control & - & - & $21.5 \mu \mathrm{g}$ & 20 \\
\hline \multicolumn{5}{|c|}{ Gram positive } \\
\hline$\gamma$ i SA & $\gamma$ i S. aureus & $2 \times 10^{5}, 2 \times 10^{7}, 2 \times 10^{9}$ & $21.5 \mu \mathrm{g}$ & 9 \\
\hline$\gamma \mathbf{i}$ BC & үi B. cereus & $2 \times 10^{5}, 2 \times 10^{7}, 2 \times 10^{9}$ & $21.5 \mu \mathrm{g}$ & 7 \\
\hline LTA & LTA & $0.3,2.9 \mathrm{mg}$ & $21.5 \mu \mathrm{g}$ & 10 \\
\hline \multicolumn{5}{|c|}{ Gram negative } \\
\hline$\gamma \mathbf{i}$ EC & $\gamma \mathrm{i}$ E. coli & $2 \times 10^{5}, 2 \times 10^{7}, 2 \times 10^{9}$ & $21.5 \mu \mathrm{g}$ & 7 \\
\hline$\gamma \mathbf{i}$ HI & $\gamma$ i H. influenzae & $2 \times 10^{5}, 2 \times 10^{7}, 2 \times 10^{9}$ & $21.5 \mu \mathrm{g}$ & 7 \\
\hline \multicolumn{5}{|c|}{ Other } \\
\hline$\gamma \mathbf{i}$ MM & үi M. marinum & $2 \times 10^{5}, 2 \times 10^{7}, 2 \times 10^{9}$ & $21.5 \mu \mathrm{g}$ & 7 \\
\hline \multicolumn{5}{|c|}{ Intramuscular osteoinduction model } \\
\hline \multirow[b]{2}{*}{ Group } & \multirow[b]{2}{*}{ Bacterial stimulus } & \multicolumn{2}{|c|}{ Concentration $(/ \mathrm{mL})$} & \multirow[b]{2}{*}{ \# Scaffolds } \\
\hline & & Bacterial stimulus & BMP-2 & \\
\hline Control & - & - & - & 20 \\
\hline \multicolumn{5}{|c|}{ Gram positive } \\
\hline$\gamma$ i SA & $\gamma \mathrm{i}$ S. aureus & $2 \times 10^{5}, 2 \times 10^{7}, 2 \times 10^{9}$ & - & 9 \\
\hline$\gamma \mathbf{i}$ BC & $\gamma$ i B. cereus & $2 \times 10^{5}, 2 \times 10^{7}, 2 \times 10^{9}$ & - & 7 \\
\hline LTA & LTA & $0.3,2.9 \mathrm{mg}$ & - & 10 \\
\hline \multicolumn{5}{|c|}{ Gram negative } \\
\hline$\gamma$ i EC & $\gamma \mathrm{i}$ E. coli & $2 \times 10^{5}, 2 \times 10^{7}, 2 \times 10^{9}$ & - & 7 \\
\hline$\gamma \mathrm{i} \mathrm{HI}$ & $\gamma$ i H. influenzae & $2 \times 10^{5}, 2 \times 10^{7}, 2 \times 10^{9}$ & - & 7 \\
\hline \multicolumn{5}{|c|}{ Other } \\
\hline$\gamma \mathbf{i} \mathbf{M M}$ & $\gamma$ i M. marinum & $2 \times 10^{5}, 2 \times 10^{7}, 2 \times 1^{09}$ & - & 7 \\
\hline
\end{tabular}

study (Bacterial comparison study, Table 2), it was determined if $\gamma$ i species that were Gram negative ( $\gamma$ i E. coli ( $\gamma \mathrm{i}$ EC)) or having both Gram negative and positive characteristics ( $\gamma \mathrm{i}$ M. Marinum ( $\gamma \mathrm{i} \mathrm{MM})$ ), had a similar potential to $\gamma$ i SA (Table 2, Tibia inoculation model). For this purpose, the medullary canal was inoculated without the addition of the prosthetic implant. To allow screening of multiple relevant bacterial species, killing methods, dose response relations, and the cell wall-derived antigen LTA in the same animals, the effect on bone formation was studied in the - previously described - ectopic osteoinduction model (Table 2) (Croes et al., 2017b; Croes et al., 2018). Blood markers were measured on day 7 to investigate the systemic effects of $\gamma \mathrm{i}$ bacterial species under minimal surgery-related conditions (Croes et al., 2017a; Odekerken et al., 2013). The amount of bone formation and immune cell infiltration were studied after 8 weeks by histology. 


\section{Bacterial culture}

Bacteria were cultured to mid-log phase. Escherichia coli (E. coli, MG1656) and S. aureus (Wood 46) were cultured in lysogeny broth (LB) medium. Bacillus cereus (B. cereus, ATCC 14579) was cultured in brain heart infusion (BHI) broth. Haemophilus influenzae (H. influenzae, NCTC 8468) was cultured in BHI broth with $\mathrm{X} \& \mathrm{~V}$ factors. Due to the health risks of handling Mycobacterium tuberculosis, Mycobacterium marinum (M. marinum, E11, kindly provided by dr. E. Houben, Molecular Microbiology, VU Amsterdam, the Netherlands) was used as an alternative pathogen to model a tuberculosis-like disease (van der Sar et al., 2004). M. marinum was grown in Middlebrook 7H9 medium with Middlebrook oleic acid-albumindextrose-catalase (BD Biosciences) and $0.05 \%(\mathrm{v} / \mathrm{v})$ Tween-80. The bacterial doses used are shown in Tables 1 and 2 .

\section{Bacterial inactivation}

Freshly cultured bacteria were killed using methods that are commonly applied in vaccine immunology. Formalin or heat killing are popular methods, but usually render the bacteria with reduced immunogenicity as compared to gamma irradiation

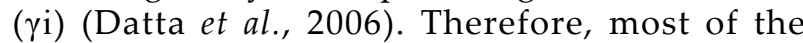
experiments were performed using $\gamma$ i killed (25 kGy, Steris, Ede, the Netherlands) bacteria. For heat inactivation, S. aureus was incubated in PBS at $60^{\circ} \mathrm{C}$ for $30 \mathrm{~min}$ under gentle agitation. For formalin inactivation, $S$. aureus were incubated overnight in $4 \%$ formaldehyde (w/v) (VWR, PA, USA) with rotation. The absence of viable bacteria was confirmed by plate cultures. After killing, bacteria were centrifuged at $5000 \times g$ for $10 \mathrm{~min}$ and washed five times with PBS prior to in vivo use.

\section{Bacterial count}

Bacterial counts were performed for the tibia groups infected with viable $S$. aureus. Immediately after sacrifice, the skin of both legs was disinfected with povidone-iodine (Betadine). After removing the skin and soft tissues using aseptic technique, the anterior peri-implant regions of the tibiae were extracted using a rotary saw (Dremel, Breda, the Netherlands). The pieces of bone $(1.4 \pm 0.6 \mathrm{~g}$ on average $)$ were processed on ice to prevent further bacterial growth. The bone samples were weighed and homogenised (Polytron PT3100; Kinetica, Best, the Netherlands). The number of colony-forming units (CFU) on blood agar plates was normalised to the weight of the bone fragments. CFU counts in the right tibiae never showed colony formation, confirming localised infection in the contaminated limb.

\section{Preparation of ectopic constructs}

Biphasic calcium phosphate (BCP) scaffolds consisted of $20 \pm 5 \% \beta$-tricalcium phosphate and $80 \pm 5 \%$ hydroxyapatite by weight, and had a total porosity of $75 \pm 5 \%$ (Xpand, Bilthoven, the Netherlands). The blocks had a dimension of $6 \times 6 \times 3 \mathrm{~mm}$. A total available pore space of $70 \mathrm{~mm}^{3}$ was considered for concentration calculations (Table 2 ), since $70 \mu \mathrm{L}$ was the maximal volume that was completely absorbed by the scaffolds. To initiate minimal osteoinductivity as previously described (Croes et al., 2017b), a suboptimal dose (15 $\mu \mathrm{L}$ of a $100 \mu \mathrm{g} / \mathrm{mL}$ suspension) recombinant human BMP-2 (InductOS, Wyeth/Pfizer, NY, USA) was first pre-adsorbed to the scaffolds. After $30 \mathrm{~min}, 55 \mu \mathrm{L}$ of a PBS suspension containing the agent of interest was loaded onto the scaffolds.

\section{Animal procedures}

Forty female New Zealand White rabbits (12-16 weeks old, $2.5-3.5 \mathrm{~kg}$, Charles River) were used with approval of the local Ethics Committee for Animal Experimentation and the Central Authority for Scientific Procedures on Animals (approved protocol AVD115002015111), in accordance with the EU Directive 2010/63/EU for animal experimentation. The rabbits were housed per 2 at the Central Laboratory Animal Institute (Utrecht University, Utrecht, the Netherlands) and were allowed to acclimatise for at least 2 weeks before the surgery. Food and water were given ad libitum. There were no unexpected adverse events and implanted samples were all retrieved.

Anaesthesia involved perioperative ketamine (15 mg/kg intra muscular (i.m.); Narketan ${ }^{\circledR}$, Vétoquinol, 's-Hertogenbosch, the Netherlands) and glycopyrrolate $\left(0.1 \mathrm{mg} / \mathrm{kg}\right.$ i.m.; Robinul ${ }^{\circledR}$, Riemser Arzneimittel AG, Greifswald, Germany), and peroperative medetomidine $(0.25 \mathrm{mg} / \mathrm{kg} \mathrm{sub}$ cutaneous (s.c.); Dexdomitor ${ }^{\circledR}$, Orion Corporation, Espoo, Finland). Anaesthesia was reversed with atipamezole hydrochloride $(0.5-1.0 \mathrm{mg} / \mathrm{kg}$ intra venous (i.v.), Atipam ${ }^{\circledR}$, Eurovet Animal Health, Bladel, the Netherlands). Buprenorphine $(0.03 \mathrm{mg} /$ kg (s.c.); Temgesic ${ }^{\circledR}$, RB Pharmaceuticals Limited, Slough, UK) was given for $2 \mathrm{~d}$ to relieve pain. The surgical procedure was performed as described before (Croes et al., 2017a).

The left stifle joint was opened through a medial para-patellar incision. In animals receiving an implant, the tibial canal was opened using a $4.1 \mathrm{~mm} \varnothing$ drill. After draining, $10^{5}$ viable bacteria or $10^{9}$ $\gamma \mathrm{i}$ bacteria were pipetted into the canal in $50 \mu \mathrm{L}$ PBS and a cylindrical sandblasted titanium $\operatorname{rod}(4 \mathrm{~mm} \varnothing$ $\times 25 \mathrm{~mm}$ ) was inserted. In the model without implant, the tibial canal was drilled with a $1.0 \mathrm{~mm} \varnothing$ drill. After draining, bacteria were injected in a volume of $50 \mu \mathrm{L}$ PBS and the opening was closed with $200-300 \mu \mathrm{L}$ fibrin glue (Tissucol $500^{\circledR}$, Baxter) to prevent leakage of the bacterial suspension. The patella and skin were closed with resorbable sutures. In vivo $\mu \mathrm{CT}$ scans of the hind limbs were made on day 28 under anaesthesia. For the tibia model, the right limbs always served as the negative control. The animals were randomly allocated to the different treatment groups using an online randomiser tool (https://www.random.org/).

Ectopic implantations were performed in the same animals receiving non-viable bacteria in the bacterial comparison study (Table 2). The BCP constructs 
were allocated to predefined implantation locations (shown in Croes et al., 2018). Each animal received ten subcutaneous scaffolds and ten intramuscular scaffolds, following a randomised block design. To minimise the influence of the scaffolds on each other, scaffolds were implanted with at least $40 \mathrm{~mm}$ lateral spacing. Apart from the scaffolds described in Table 2, the rabbits received non-proinflammatory ceramic scaffolds which are not related to the current study.

The animals' bodyweight was measured weekly. Blood was collected pre-operatively, and on days $3,7,14$ and 28 to measure systemic markers of inflammation. To trace new bone formation, fluorochrome labels Xylenol orange $(30 \mathrm{mg} / \mathrm{kg}$ s.c. in $1 \% \mathrm{w} / \mathrm{v} \mathrm{NaHCO}_{3}$ ) and calcein green $(10 \mathrm{mg} / \mathrm{kg}$ s.c. in $2 \% \mathrm{w} / \mathrm{v} \mathrm{NaHCO}_{3}$ ) were injected at indicated time points.

Animals were euthanised with pentobarbital (i.v. Euthanimal ${ }^{\circledR}$, Alfasan, Woerden, the Netherlands) under same anaesthesia as the surgery. The hind limbs were harvested and immediately scanned by $\mu \mathrm{CT}$.

\section{$\mu \mathrm{CT}$ analysis}

Scans were acquired with a tube voltage of $90 \mathrm{kV}$ and tube current of $180 \mu \mathrm{A}$ (Quantum FX, PerkinElmer, MA, USA). Images were represented as a stack of 2D TIFF images (Analyze, version 11.0, AnalyzeDirect Inc, KS, USA). All analyses were performed with the BoneJ plugin (version 1.3.12) in ImageJ freeware version 1.48 (U.S. National Institutes of Health). The intramedullary implant was excluded using a customised macro in ImageJ based on a global threshold. An adaptive threshold was applied based on the mean local grey scale distribution to segment the bone for volume and porosity measurements.

For the tibia implant model (voxel size $60 \mu \mathrm{m}^{3}$ ), analyses were performed separately on the proximal implant-containing (280 slices, $16.8 \mathrm{~mm}$ ) and distalto-implant (220 slices, $13.2 \mathrm{~mm}$ ) tibial sections. The proximal and distal fusion points between tibia and fibula were used as reference to cover the same bone area. In the model without implant (voxel size $120 \mu \mathrm{m}^{3}$ ), analyses were performed on a tibial section (250 slices, $30 \mathrm{~mm}$ ) proximal of the distal fusion between tibia and fibula. Grey value profile plots of the middle slices were used to assess changes in bone density.

\section{Tissue processing}

For the tibia implant model, a bone sample immediately distal to the implant was used for decalcified histology. In the model without implant, a bone sample was taken just proximal to the fusion point between tibia and fibula. The bone samples where fixed in $4 \%$ formaldehyde $(\mathrm{w} / \mathrm{v})$ for $3 \mathrm{~d}$ and decalcified in $0.3 \mathrm{M}$ ethylenediaminetetraacetic acid (EDTA) (VWR) for three weeks. The EDTA was replaced by formaldehyde for $2 \mathrm{~d}$ at halfway, and for $2 \mathrm{~d}$ at the end of the decalcification procedure. Subsequently, $6 \mu \mathrm{m}$-thick cross-sections were cut for histological staining. The rest of the tibia was fixed in $4 \%$ formaldehyde $(\mathrm{w} / \mathrm{v})$ for $3 \mathrm{~d}$ and dehydrated in an ethanol series. After embedding in methyl methacrylate (MMA) (VWR), $35 \mu$ m-thick sections were cut using a saw microtome. The same fixation/ decalcification protocol was used for histological preparation of BCP scaffolds. A quarter of each construct was decalcified and sectioned after paraffin embedding. The remaining construct was used for MMA histology.

\section{Scoring of bone changes}

Periosteal bone formation, enlargement of Haversian canals, and cortical bone loss were scored on basic fuchsin/methylene blue-stained MMA sections. The parameters were scored by two observers (MC and SAP) on blinded samples as 0 (absent), 1 (moderate), or 2 (severe) according to the portion of the cortical circumference that was affected relative to untreated contralateral tibiae. The average value of the two observers was used for further analyses. Measurements in the untreated tibiae showed that Haversian canals should be defined as enlarged for a diameter exceeding $100 \mu \mathrm{m}$.

\section{Bone histomorphometry}

MMA sections were stained with basic fuchsin and methylene blue. Two midsections were pseudocoloured in Adobe Photoshop CS6 (Adobe Systems) to quantify the percentage of bone tissue in the available pore space (bone area \%). The mean value of two midsections per sample was used for statistical analyses.

\section{Fluorochrome detection}

Two blinded observers (MC and SAP) scored the presence of fluorochromes in unstained MMA sections. Fluorochrome overview images were taken with a laser scanning confocal microscope (SP8X, Leica). Sections were imaged using a $10 \times$ dry objective and a white light laser (470-670 nm). Hybrid detectors collected fluorescence signal from calcein (494/509-550 nm) and xylenol orange (570/610$780 \mathrm{~nm}$ ), which were given the pseudo-colours green and red. All images were processed using Leica LASX acquisition software.

\section{Histological staining}

For Gram staining, decalcified bone samples were treated with $10 \%(\mathrm{w} / \mathrm{v})$ crystal violet (Sigma Aldrich, MO, USA) followed by Lugol's solution(Sigma Aldrich). Differentiation was performed with acetone, following by staining with $10 \%$ (v/v) Ziehl-Neelsen's carbol fuchsin (Merck Millipore, MA, USA). Picric acid was used as a counterstain (VWR). To localise Gram-positive bacteria, a modified Gram stain was used in which samples were counterstained with $0.05 \%(w / v)$ light green SF (Sigma Aldrich) after the 
differentiation step. To identify mycobacteria, an acid-fast bacteria stain kit was used according to the manufacturer's instructions (Dako). Tartrate-resistant acid phosphatase (TRAP) activity was visualised to demonstrate the presence of osteoclasts as described before (Croes et al., 2017a). Immunohistochemical staining was performed as previously described in detail (Croes et al., 2017b). A mouse-anti-human calprotectin antibody $(5 \mu \mathrm{g} / \mathrm{mL}$, MCA874A488, clone MAC387, Bio-rad) was used to detect activated macrophages and neutrophils. For detection of $\mathrm{T}$ lymphocytes, a mouse-anti-human CD3 antibody (0.7 mg/mL, M7254, clone F7.2.38, Dako) was used. For each sample, the total number positively-stained cells in one cross section was counted.

\section{Statistical analyses}

All data are presented as mean \pm standard deviation (SD), with the group sizes indicated in the figure legends. SPSS version 20.0 was used (IBM). Repeated measures ANOVA was performed to analyse changes in bodyweight or levels of systemic inflammation markers. One-way ANOVA was performed to compare bone changes on MMA samples. A paired sample t-test was used to analyse differences in bone volume between treated and untreated limbs on $\mu \mathrm{CT}$. Differences in ectopic bone volume (bone area \%) were analysed using a linear mixed-model approach. Pairwise comparisons were made between $\gamma \mathrm{i}$ bacteria or LTA-loaded scaffolds and the control sample in each animal. Within this model, the TEST subcommand was used to test the hypothesis that the highest concentration of bacteria results in a lower bone volume compared to the other concentrations. A post hoc test with Bonferroni correction was used. The group sizes used in this study were based on sample size analyses, using a power of $80 \%$ and an alpha of $5 \%$ that was adjusted for multiple comparisons. An effect size of $30 \%$ and standard deviation of $20 \%$ was used.

\section{Results}

\section{Bacterial count and inflammatory responses following tibial treatment}

There were considerable differences in the inflammatory responses between groups, related to the SA viability and presence of a titanium implant (Fig. 1). A transient reduction in bodyweight was observed in all groups in the first week. Only animals from the SA + Ti group did not regain their normal weight by day 28 (Fig. 1b). All groups showed increased levels of systemic inflammation markers in the first $3 \mathrm{~d}$ after surgery (Fig. 1c), which normalised by day 7 in the $\gamma \mathrm{i}$ SA + Ti group and by day 14 in the SA and SA + Ti groups. The number of live bacteria retrieved at day 28 (Fig. 1d) was 100-fold higher in the $\mathrm{SA}+\mathrm{Ti}$ group $\left(1.9 \pm 2.1 \times 10^{6} \mathrm{CFU} / \mathrm{g}\right.$ bone $)$ than the SA group $\left(1.9 \pm 2.1 \times 10^{4} \mathrm{CFU} / g\right.$ bone $)$. No colonies could be cultured from any of the bones from the үi SA + Ti group, but diffuse Gram-positive staining indicated the presence of bacterial cell walls or their remnants in the bone marrow (Fig. 1e).

\section{Pro-osteogenic and osteolytic effects of $S$. aureus in the tibia}

Both the pro-osteogenic and osteolytic effects of viable and $\gamma$ i killed $S$. aureus were shown in the rabbit tibia model (Fig. 1a). Qualitative $\mu \mathrm{CT}$ analysis demonstrated mild cortical osteolysis in the endosteal region in the SA group (Fig. 2a). In the SA + Ti and $\gamma \mathrm{i} \mathrm{SA}+\mathrm{Ti}$ groups, osteolytic changes were accompanied by cortical thickening indicating new bone formation. The more profound cortical resorption in the SA + Ti group occasionally resulted in a separation between the subperiosteum and cortex. Quantitative $\mu \mathrm{CT}$ analyses showed a significant increase in the cortical bone porosity in all treated groups compared to the contralateral tibia (Fig. 2b). The bone volume was quantified separately for the proximal (peri-prosthetic) and distal tibial regions to establish the role of the implant in the osteogenic response (Fig. 2c). Accordingly, a significant bone volume increase $(+89 \%, p=0.047)$ was confined to the peri-prosthetic infection region in the SA + Ti group, whereas $\gamma \mathrm{i} \mathrm{SA}+\mathrm{Ti}$ induced a bone volume increase in both the proximal (+ $18 \%$, $p=0.019)$ and distal $(+28 \%, p=0.003)$ tibia.

The incorporation of injected fluorochrome markers at sites of mineralisation was assessed to trace the location and progression of bone formation in time (Fig. 2d). In comparison to untreated contralateral tibiae, the abundant presence of fluorochromes was indicative of increased bone deposition in both the $\mathrm{SA}+\mathrm{Ti}$ and $\gamma \mathrm{i} \mathrm{SA}+\mathrm{Ti}$ groups. Bone apposition had an onset before day 3 and was visible throughout the entire study period. Histological assessment showed osteomyelitis-like bone changes in all groups, but cortical bone loss was almost exclusively observed in the SA + Ti group (Fig. 2e, Fig. 2f). The amount of osteolysis in the different groups was associated with the relative presence of osteoclasts (Fig. $2 \mathrm{~g}$ ).

\section{Bacterial species-dependency in the tibial osteogenic response}

The bacterial comparison study (Fig. 3a) involved different species of $\gamma$ i bacteria ( $\gamma \mathrm{i}$ SA, $\gamma \mathrm{i}$ EC and $\gamma \mathrm{i} \mathrm{MM}$ ) in the tibia model. No implant was used, based on the observation that $\gamma \mathrm{i}$ SA also promoted bone formation distal to the implant (Fig. 2c) and which suggests that the role of the implant is negligible in $\gamma$ i bacteriainduced osteogenesis. All animals already loaded their treated limb from the second post-operative week onward, and there was no apparent influence on their bodyweight (data not shown). The systemic responses of the animals were mostly characterised by increased leukocyte numbers at day 7 , while the erythrocyte sedimentation rate was not elevated compared to animals previously undergoing sham operation with implant alone (Table 3) (Croes et al., 2017a). 

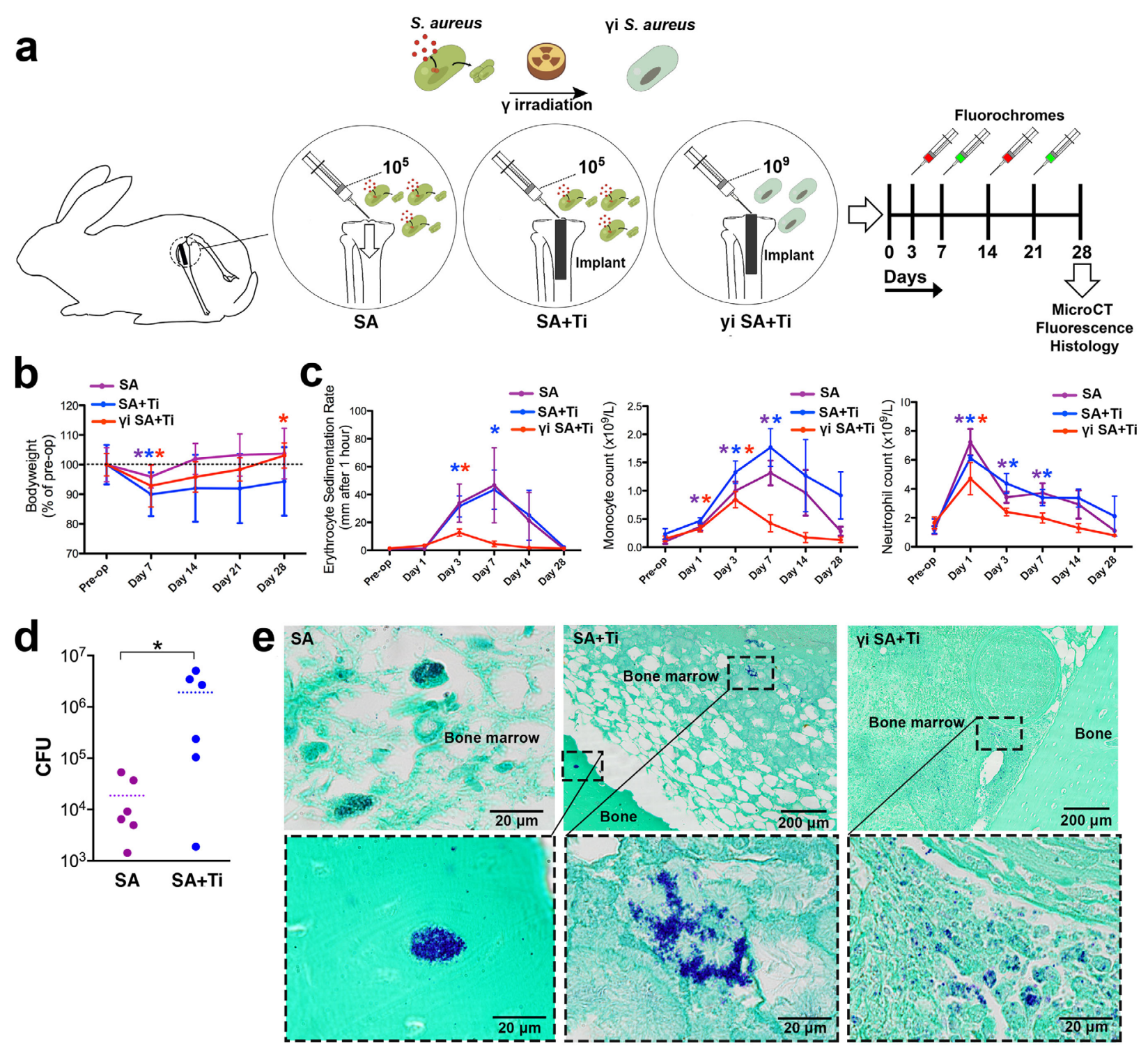

Fig. 1. Effect of viable and killed $S$. aureus on the systemic inflammatory response. (a) Viable $S$. aureus were studied either in absence (SA) or presence (SA + Ti) of a metal implant in the rabbit tibia. Gamma irradiation-killed S. aureus were also studied together with an implant $(\gamma \mathrm{i} \mathrm{SA}+\mathrm{Ti})$. Fluorochromes were injected to determine the onset and dynamics of bone formation. The tibial bone changes were measured after $28 \mathrm{~d}$. (b) Relative bodyweight changes as compared to the pre-operative value. (c) Systemic inflammation as determined by the erythrocyte sedimentation rate and leukocyte counts. (d) Bacterial count in SA and SA + Ti bone specimens retrieved after $28 \mathrm{~d}$ in terms of the number colony-forming units (CFU) (e) Representative cross-sections of tibiae stained for Gram-positive bacteria or cell walls (blue). Data represent the mean $\pm \mathrm{SD}$ for the SA $(n=6), \mathrm{SA}+\mathrm{Ti}(n=6)$, and $\gamma \mathrm{i} \mathrm{SA}+\mathrm{Ti}(n=8)$ groups. ${ }^{*} p<0.05$ compared to the pre-operative value, repeated measures ANOVA with Bonferroni correction for post hoc analysis.

Table 3. Non-specific markers of systemic inflammation measured at day 7 in the bacterial comparison study. ESR: erythrocyte sedimentation rate, $\gamma \mathrm{i}$ : gamma irradiation-killed. Data are presented as the mean \pm SD for $\gamma \mathrm{i} S$. aureus $(n=6), \gamma \mathrm{i}$ E. coli $(n=7)$, and $\gamma \mathrm{i}$ M. marinum $(n=7)$.

\begin{tabular}{|l|c|c|c|}
\hline & $\gamma$ i S. aureus & $\gamma \mathrm{i}$ E. coli & $\gamma$ i M. marinum \\
\hline ESR $(\mathbf{m m} / \mathbf{h})$ & $1.7 \pm 0.8$ & $1.4 \pm 0.5$ & $2.2 \pm 0.7$ \\
\hline Leukocytes $(\times \mathbf{1 0} 9 / \mathrm{L})$ & $8.2 \pm 2.3$ & $13.0 \pm 3.7$ & $10.0 \pm 2.2$ \\
\hline Monocytes $(\times \mathbf{1 0} / \mathbf{L})$ & $0.6 \pm 0.2$ & $1.1 \pm 0.6$ & $1.0 \pm 0.4$ \\
\hline Neutrophils $(\times \mathbf{1 0} / \mathbf{L})$ & $1.9 \pm 0.6$ & $4.4 \pm 1.7$ & $2.9 \pm 1.3$ \\
\hline
\end{tabular}



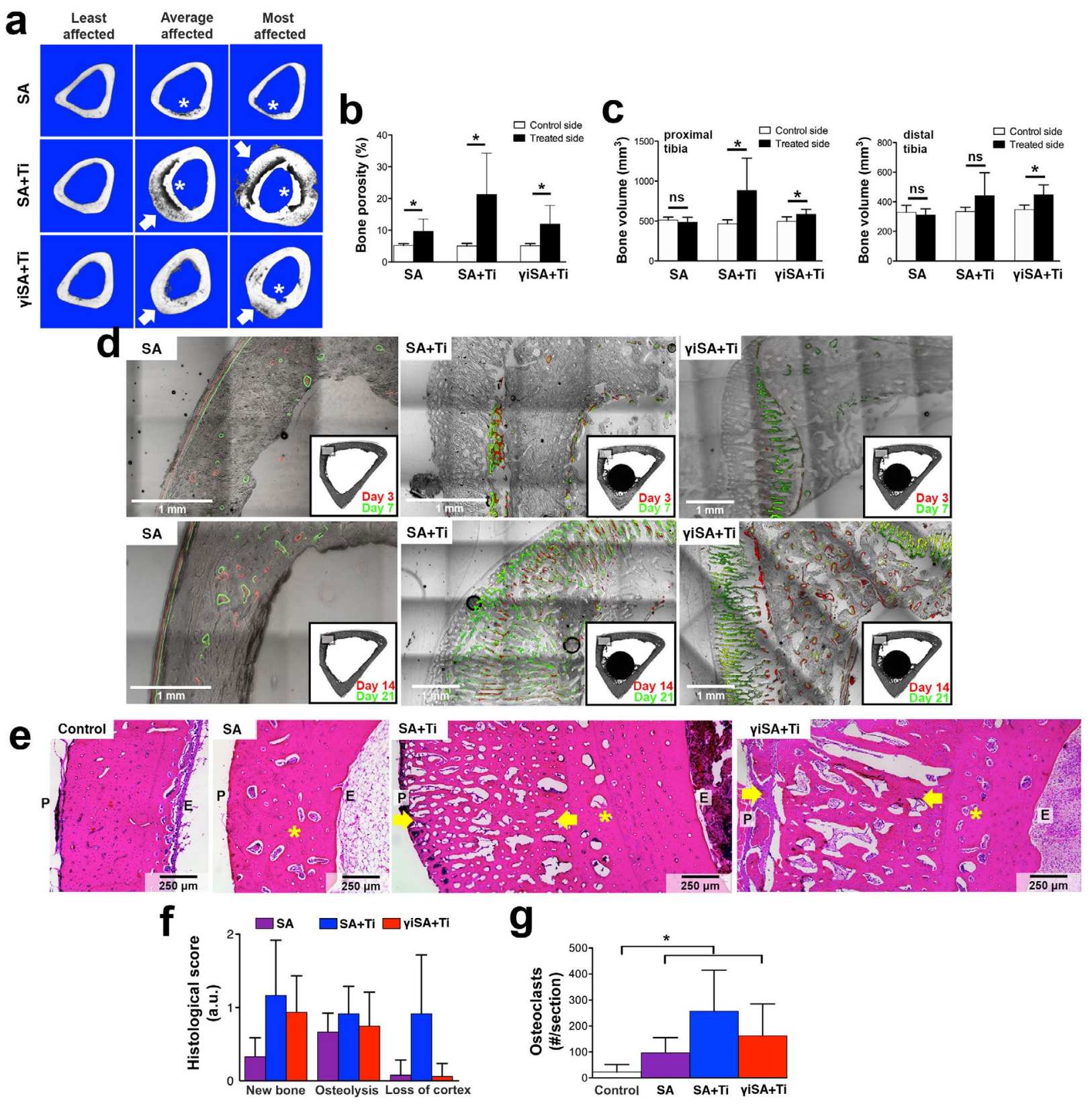

Fig. 2. Effect of viable and killed S. aureus on the local bone changes $28 \mathrm{~d}$ after bacterial inoculation. (a) Representative $\mu \mathrm{CT}$ images of middle sections of the tibiae. Arrows: periosteal bone formation. Asterisks: osteolysis. (b) Cortical bone porosity measured by $\mu \mathrm{CT}$. (c) Tibial bone volume in the peri-prosthetic (left) or distal-to-implant bone region (right) as measured by $\mu \mathrm{CT}$. (d) Overlay images of brightfield and fluorescence channels demonstrating incorporation of xylenol orange (red) and calcein (green) during bone deposition in tibiae treated with viable or $\gamma \mathrm{i}$-killed S. aureus on days $3 / 7$ (upper panel) and days 14/21 (lower panel). (e) H\&E staining of an untreated contralateral tibia and the most affected tibiae after treatment with viable $S$. aureus without (SA) or with (SA + Ti) implant, or gamma irradiation-killed S. aureus with implant ( $\gamma \mathrm{i} \mathrm{SA}+\mathrm{Ti})$. The regions between the arrows indicate newly formed bone. The asterisks indicate osteolysis. $\mathrm{P}=$ periosteum, $\mathrm{E}=$ endosteum. (f) Scoring of bone changes in the tibiae. $0=$ absent, $1=$ moderate, $2=$ severe. $(\mathrm{g})$ Osteoclasts detected by tartrate-resistant acid phosphatase (TRAP) staining on sections from untreated contralateral tibiae (control) or tibiae treated with viable or $\gamma \mathrm{i}$ bacteria. Data represent the mean $\pm \mathrm{SD}$ for the SA $(n=6)$, $\mathrm{SA}+\mathrm{Ti}(n=6)$, and $\gamma \mathrm{i} \mathrm{SA}+\operatorname{Ti}(n=8)$ groups. $\mathbf{b}$ and $\mathbf{c}:{ }^{*} p<0.05$; paired sample $t$-test with Bonferroni post hoc test. g: ${ }^{*} p<0.05$; one-way ANOVA with Bonferroni correction for post hoc analysis. 

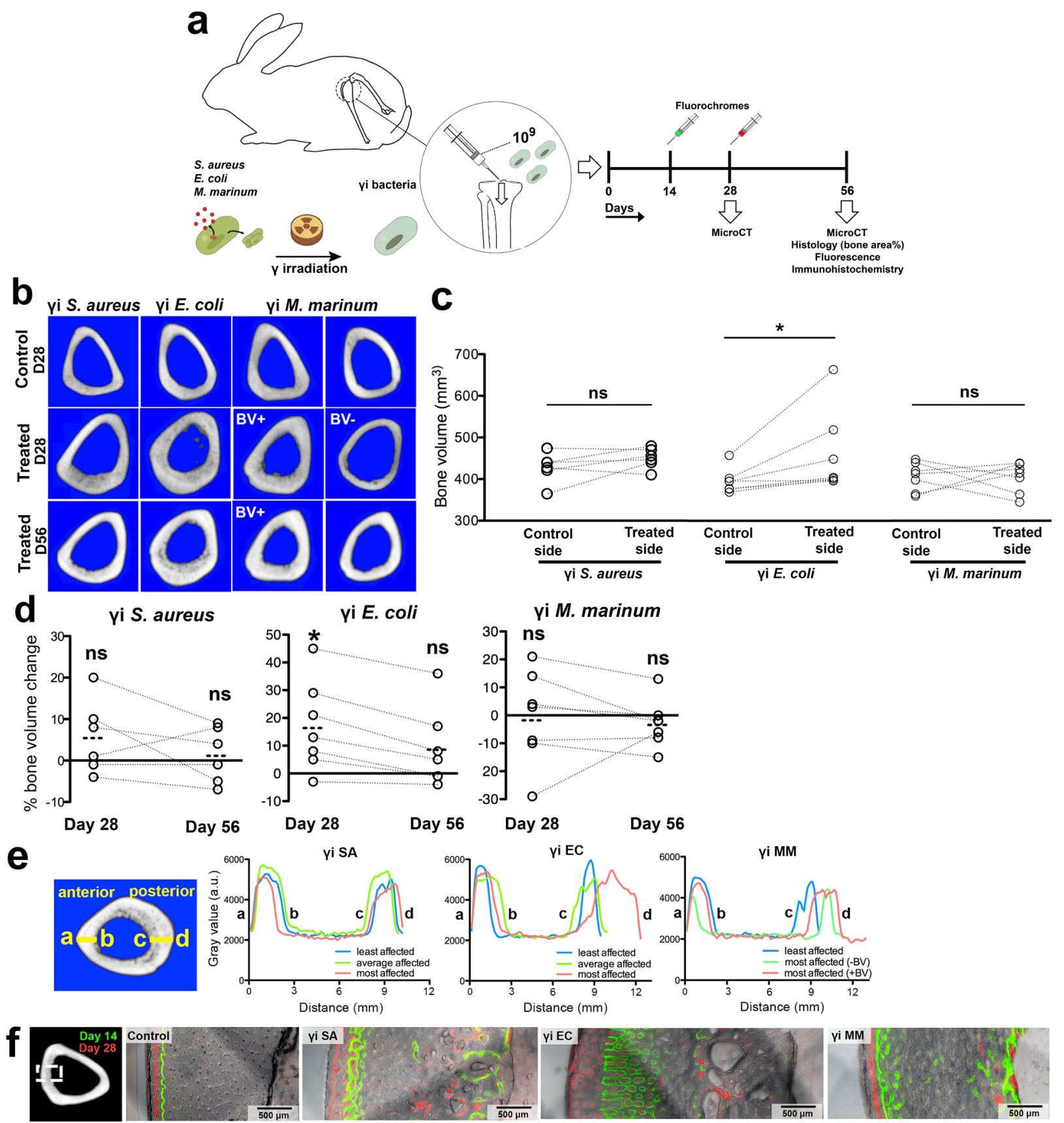

Fig. 3. Species-related effects of killed bacteria on the pro-osteogenic response. (a) Gamma irradiation-killed ( $\gamma$ i) bacteria were injected into the tibial medullary cavity. Fluorochromes were injected to determine the onset and dynamics of bone formation. The tibial bone changes were measured by $\mu \mathrm{CT}$ after 28 and $56 \mathrm{~d}$. (b) $\mu \mathrm{CT}$ images of the middle section of the tibiae shows changes in cortical thickness in untreated tibiae, or in tibiae inoculated with $\gamma \mathrm{i}$ bacteria. Images are shown for the most affected sample in each group at day 28 or day 56. (c) Tibial bone volume as measured by $\mu \mathrm{CT}$ of $\gamma \mathrm{i}$-bacteria treated limbs and the respective contralateral (control side) limbs. (d) Quantitative $\mu \mathrm{CT}$ measurement of the tibial bone volume on days 28 and 56 after treatment with $\gamma \mathrm{i}$ bacteria. The fold bone volume increase is shown for each rabbit when comparing the treated to untreated tibia. Data represent the mean $\pm \mathrm{SD}$ for $\gamma \mathrm{i}$ S. aureus $(\mathrm{SA}, n=6), \gamma \mathrm{i}$ E. coli $(\mathrm{EC}, n=7)$, and yi M. marinum (MM, $n=7$ ). ${ }^{*} p<0.05$; paired sample $t$-test with Bonferroni correction for post hoc analysis. (e) In order to describe the location and direction of bone density changes, the $\mu \mathrm{CT}$ grey values along a line extending the cortex in anterior to posterior direction were plotted. Values are shown for samples with the least, average, or largest change in bone volume in each group treated with $\gamma$ i bacteria. (f) Overlay images of brightfield and fluorescence channels demonstrating the incorporation of calcein (green, day 14) and xylenol orange (red, day 28) in tibia sections. The images are representative for the untreated contralateral tibiae (control), or tibiae treated with $\gamma$ i bacteria. 

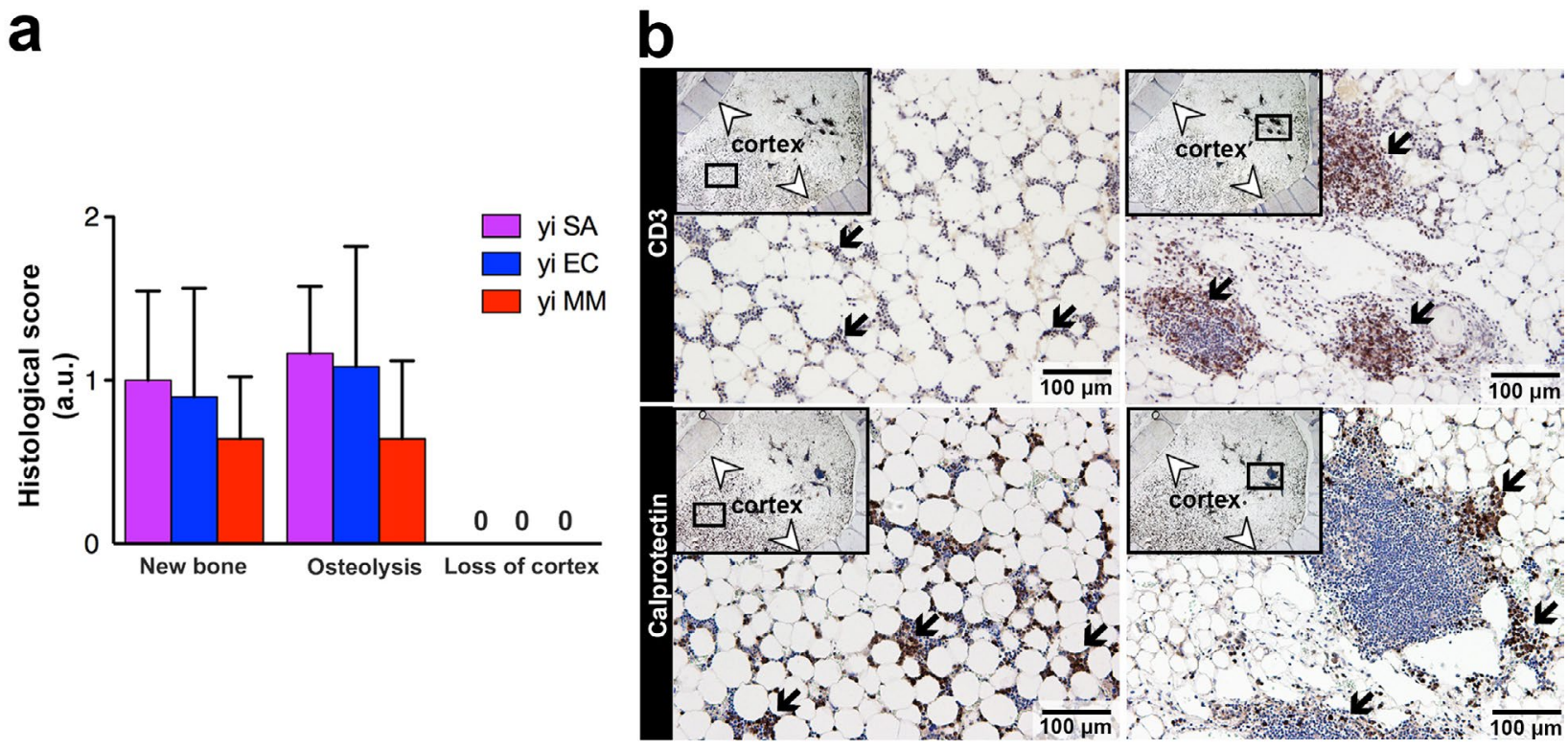

Fig. 4. Species-related effects of killed bacteria on bone histological changes. (a) Day 56 scoring of regional bone changes in the rabbit tibiae. $0=$ absent, 1 = moderate, $2=$ severe. $($ b) Day 56 staining for $\mathrm{T}$ lymphocytes (CD3) and activated macrophages/neutrophils (Calprotectin) at two different bone marrow locations after treatment with $\gamma \mathrm{i}$ M. marinum. This image is representative for samples of the $\gamma \mathrm{i}$ M. marinum and $\gamma \mathrm{i}$ E. coli groups.

Day $28 \mu \mathrm{CT}$ showed most consistent cortical thickening in tibiae of the $\gamma \mathrm{i}$ SA and $\gamma \mathrm{i}$ EC groups (Fig. $3 \mathbf{b}$ ). The bacterial species affected the tibial bone volume differently (Fig. 3c). ri SA induced an average $5 \%$ bone volume increase with a high interindividual variation. In comparison, six out of seven animals of the $\gamma \mathrm{i}$ EC group demonstrated an increased bone volume of the treated tibia (16\% increase on average, $p=0.028$ ). The effect of $\gamma \mathrm{i} \mathrm{MM}$ was variable and did not affect the average bone volume. The experiment was extended to $56 \mathrm{~d}$ to characterise the dynamics of the bone changes, and showed that the bone volume increases had largely regressed at this time point (Fig. 3d). Cortical thickening was associated with a modest decrease in the bone density (Fig. 3e). Fluorochrome incorporation showed that the pro-osteogenic response was localised mainly to the periosteal surface, and was most pronounced in the $\gamma$ i EC group (Fig. 3f).

To describe the location and direction of bone density changes, the $\mu \mathrm{CT}$ grey values along a line extending the cortex in anterior to posterior direction were plotted. This showed that cortical thickening was associated with only a modest decrease in the bone density. Enhanced bone porosity and periosteal new bone formation as seen by $\mu \mathrm{CT}$ was confirmed by histological evaluation (Fig. 4a). Different staining methods showed no evidence of remaining bacterial components. Immunohistochemistry demonstrated mixed innate (i.e. macrophages/neutrophils) and adaptive (i.e. T lymphocytes) immune cell infiltrations in the bone marrow of samples of the $\gamma \mathrm{i} \mathrm{MM}$ and $\gamma \mathrm{i} \mathrm{EC}$ groups (Fig. 4b). Only few osteoclasts were observed at the periosteal lining in the different groups (not shown).

\section{Effect of bacterial immune agonists on ectopic bone induction}

The effect of microbial stimuli on ectopic bone induction was also investigated. None of the empty or $\gamma \mathrm{i}$ bacteria-loaded ceramic scaffolds implanted intramuscularly induced a relevant amount of bone, i.e. $>1 \%$ bone area \% (not shown). In scaffolds carrying a suboptimal dose of BMP-2 (Fig. 5a), bone tissue was observed in various amounts (Fig. 5b). A promotive effect of $\gamma \mathrm{i}$ bacteria on new bone formation was measured when applied at a concentration of $2 \times 10^{5}-2 \times 10^{7} / \mathrm{mL}$ (Fig. 5 c). A high load of bacteria $\left(2 \times 10^{9} / \mathrm{mL}\right)$ was associated with a significantly lower $(p<0.05)$ bone volume compared to the constructs loaded with a low $\left(2 \times 10^{5} / \mathrm{mL}\right)$ or medium $\left(2 \times 10^{7} /\right.$ $\mathrm{mL}) \gamma \mathrm{i}$ bacterial load, irrespective of the bacterial species. The presumed change in immunogenicity due to commonly used bacterial inactivation methods indeed modified the pro-osteogenic effects of $\gamma \mathrm{i}$ SA. The stimulatory effect of SA on ectopic bone formation was most pronounced following formalin killing (Fig. 5d). Heat killing appeared to decrease the responsiveness to $S$. aureus as shown by the reversed concentration-response curve relative to the other inactivation methods, which is likely due to the destructive effects of high temperatures on bacterial cell wall proteins (Rockel et al., 2011). The S. aureus cell-wall-derived TLR2 activator lipoteichoic acid 
a

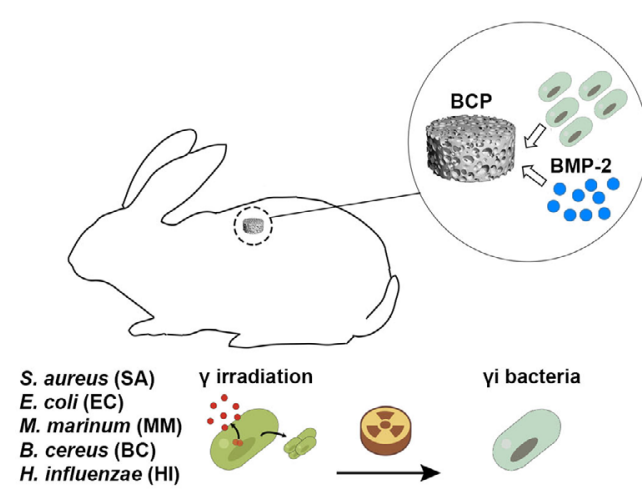

C $\star$ d

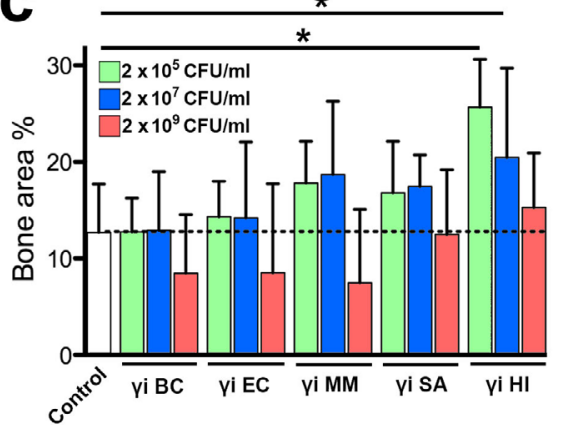

b
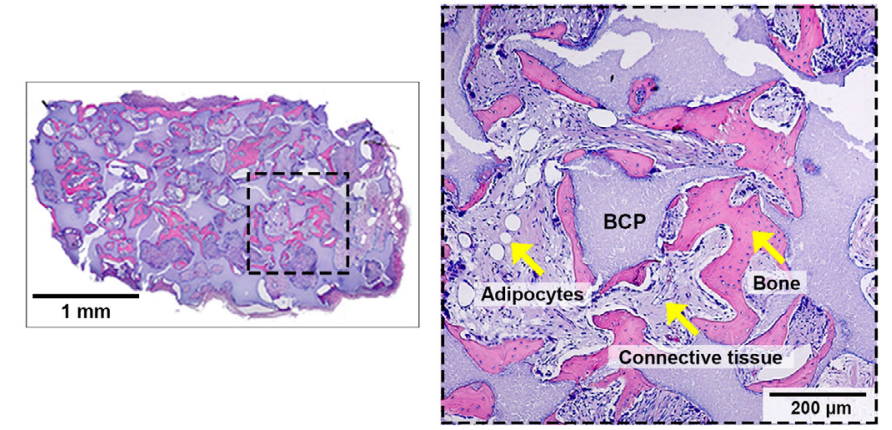

e

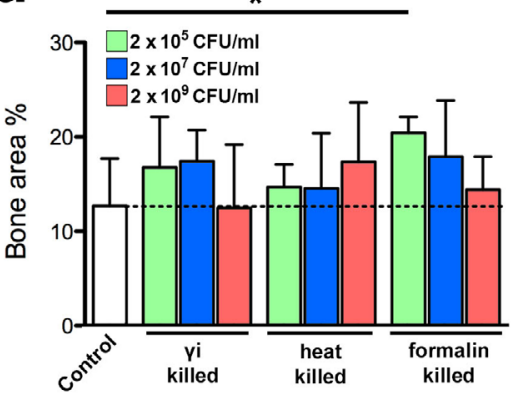

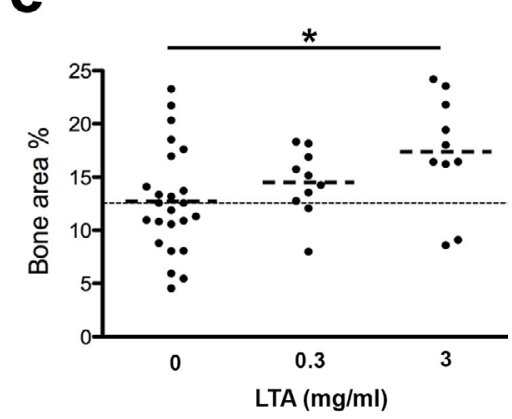

Fig. 5. Effect of killed bacteria on new bone formation in bone scaffolds. (a) Porous biphasic calcium phosphate (BCP) scaffolds were pre-adsorbed with a suboptimal dose bone morphogenetic protein-2 (BMP-2), and subsequently loaded with gamma irradiation-killed ( $\gamma$ i) bacteria. The bone volume and inflammatory response in the scaffolds were evaluated after 8 weeks. (b) Histology of a methylene blue and basic fuchsin-stained section, representative for the control samples with BMP-2 alone. (c) Bone volume in constructs implanted in subcutaneous pockets in rabbits. Samples were loaded with $21.5 \mu \mathrm{g} / \mathrm{mL}$ BMP-2 alone (control) or $21.5 \mu \mathrm{g} / \mathrm{mL}$ BMP-2 together with a dose range of $\gamma \mathrm{i}$ bacteria. (d) Bone volume in constructs implanted in subcutaneous pockets in rabbits, loaded with $21.5 \mu \mathrm{g} / \mathrm{mL}$ BMP-2 alone (control) or $21.5 \mu \mathrm{g} / \mathrm{mL}$ BMP-2 in combination with $S$. aureus killed by different methods. (e) Bone volume in constructs implanted in subcutaneous pockets in rabbits, loaded with $21.5 \mu \mathrm{g} / \mathrm{mL}$ BMP-2 alone or BMP-2 in combination with lipoteichoic acid (LTA). Data represent the mean \pm SD for the control group $(n=24)$, LTA groups $(n=10)$ and $\gamma$ i bacteria groups $(n=7-9) .{ }^{*} p<0.05$; linear mixed-model with Bonferroni correction for post hoc analysis. $\mathrm{BC}=$ B. cereus, $\mathrm{EC}=E$. coli, $\mathrm{MM}=M$. marinum, $\mathrm{SA}=S$. aureus, $\mathrm{HI}=H$. influenzae.

(LTA) was found to dose-dependently enhance bone induction (Fig. 5e), strengthening an involvement of cell wall-associated antigens in the pro-osteogenic response to $\gamma$ i bacteria.

Histology showed increased immune cell infiltrations in scaffolds loaded with $\gamma \mathrm{i}$ bacteria. The local immune response was characterised by a mixed population of $\mathrm{T}$ lymphocytes and calprotectinexpressing phagocytes (Fig. 6a). These leukocyte subsets were quantified in the BMP-2 constructs loaded with BMP-2 and a low $\left(2 \times 10^{5} / \mathrm{mL}\right)$ or a high $\left(2 \times 10^{9} / \mathrm{mL}\right)$ dose of $\gamma \mathrm{i}$ bacteria, since these conditions mediated opposite effects on new bone formation. The highest dose of bacteria generally coincided with a higher number of T lymphocytes (Fig. 6b), while such a dose-dependent effect was less apparent for the phagocytes (Fig. 6c). As a potential mechanism for the decreased bone formation due to high dose $\gamma \mathrm{i}$ bacteria, sustained inflammation was found to induce exaggerated osteoclast activity (Fig. 6d): although TRAP-positive osteoclasts were generally localised at areas of new bone formation, numerous osteoclasts could be found in absence of any bone in samples loaded with the highest dose $\gamma \mathrm{i}$ MM or $\gamma \mathrm{i}$ SA.

\section{Discussion}

Immune modulation is a potential strategy to enhance the osteogenic activity of bone substitutes (Chen et al., 2016; Mountziaris et al., 2011). The use of bacterial immune agonists has recently received more attention. We previously showed that $S$. aureusmediated peri-prosthetic infection leads to gross signs of both osteolysis and quantifiable new bone formation. Since virulent bacteria are unlikely to be used in musculoskeletal regenerative therapies, further research is warranted to identify bacterial 


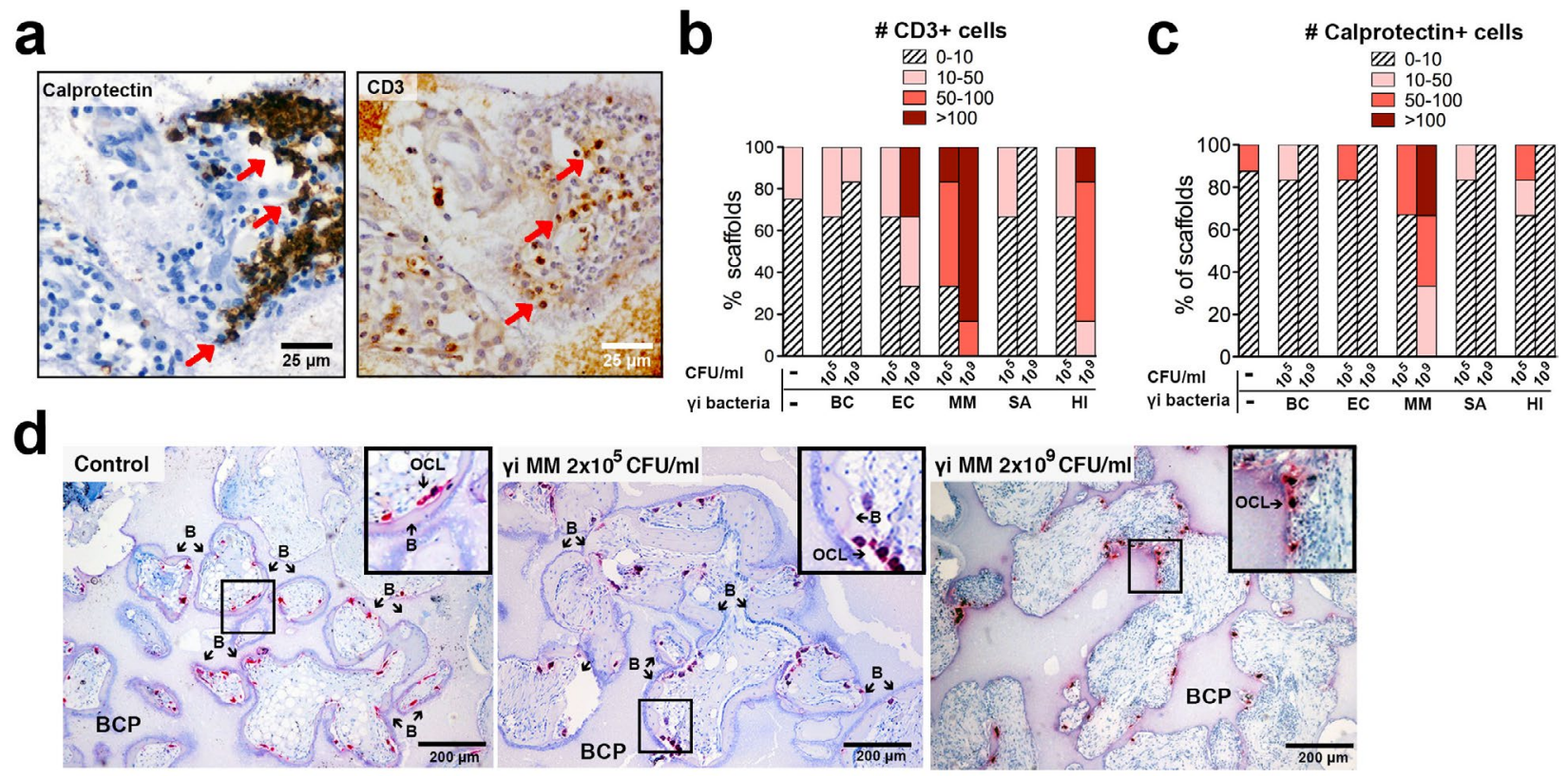

Fig. 6. Effect of killed bacteria on the inflammatory response in bone scaffolds. (a) Representative immunostaining for calprotectin-expressing phagocytes and CD3-positive $\mathrm{T}$ lymphocytes on consecutive BCP sections loaded with BMP-2 and $2 \times 10^{9} / \mathrm{mL}$ yi M. marinum. $(\mathbf{b}, \mathbf{c})$ Total T lymphocyte $(\mathbf{b}, \mathrm{CD} 3)$ and macrophage/neutrophil (c, Calprotectin) counts/section in BCP constructs loaded with BMP-2 alone (control) or BMP-2 and $\gamma \mathrm{i}$ bacteria, implanted in subcutaneous pockets. (d) Tartrate-resistant acid phosphatase (TRAP) staining to demonstrate bone (B)- or scaffold-lining osteoclasts (OCL, red) in samples loaded with BMP-2 alone, or BMP-2 in combination with $2 \times 10^{5}-10^{9} / \mathrm{mL}$ $\mathrm{i}$ M. marinum (representative for the $\gamma \mathrm{i}$ M. marinum and $\gamma \mathrm{i}$. aureus groups). $\mathrm{BC}=B$. cereus, $\mathrm{EC}=E$. coli, $\mathrm{MM}=M$. marinum, $\mathrm{SA}=S$. aureus, $\mathrm{HI}=H$. influenzae.

components or downstream secreted cytokines which can be harnessed as a safer alternative. A top-down approach was followed to test the hypothesis that the inflammatory reaction to killed bacteria would lead to more favourable bone formation as compared to their viable counterpart, and also investigated whether non-viable bacterial agonists can promote ectopic new bone formation in bone scaffolds.

In a rabbit tibia model, it was shown as proof-ofprinciple that local application of gamma irradiationkilled $(\gamma \mathrm{i})$ bacterial species circumvents the hazards of infection in terms of uncontrolled spread and systemic interference. Accordingly, even a $10^{4}$-fold higher challenge with $\gamma \mathrm{i} S$. aureus compared to viable $S$. aureus, led to a more transient immune response and more favourable bone tissue formation. This is largely explained by the fact that active infection causes bone loss through local production of exotoxins that target host cells or factors that degrade the extracellular matrix (Lew and Waldvogel, 2004). In addition, infection-related systemic inflammation can activate bone catabolic pathways (Kim et al., 2013). Despite the net bone volume increase induced by local application of $\gamma \mathrm{i}$ bacteria, the delivery of clinically-applied bisphosphonates or anti-RANKL/ cytokines antibodies can possibly skew the response towards even more improved bone formation by diminishing unbalanced osteoclastogenesis (Genêt et al., 2015; Marriott, 2013; Redlich and Smolen,
2012). Selective inhibition of osteoclasts in the tibia model can also provide clues as to the importance of osteoclast-osteoblast coupling in the observed osteogenic response (Gamblin et al., 2014; Genet et al., 2015; Takeshita et al., 2013).

Different species of killed bacteria were compared in a first step towards identifying their pro-osteogenic components, considering that bone formation during infection has been almost exclusively assessed for $S$. aureus in osteomyelitis animal models (Cassat et al., 2013; Pavey et al., 2015; Stadelmann et al., 2015). While few comparative studies suggest that immune agonists from Gram-positive and Gram-negative bacteria may affect ectopic new bone formation differently (Croes et al., 2017b; Pavey et al., 2015), similar bone changes were observed for $\gamma \mathrm{i} S$. aureus (Gram-positive) and $\gamma \mathrm{i}$ E. coli (Gram-negative) in the tibia. In the ectopic induction model, dose-dependent effects on ectopic bone formation were seen for $\gamma \mathrm{i}$ bacterial species with different Gram classifications, and Gram-negative $H$. influenzae significantly enhanced ectopic bone formation. Accordingly, it is impossible to narrow down the osteo-immunomodulatory effects of the tested $\gamma \mathrm{i}$ bacteria to specific (cell wall-derived) immune agonists. Rather than comparing the proosteogenic activity of different bacterial species, more mechanistic studies with one chosen species can be a more straightforward avenue to elucidate the critical pathways involved in bone induction. For example, 
a comparison of the activity of $S$. aureus in wild type and knockout mice can be a way of pinpointing proosteogenic immune agonists, such as the pathways mediated by $S$. aureus-derived LTA or peptidoglycan through TLR-2 (Kim et al., 2013; Wang et al., 2015). Alternatively, single bacterial components can be studied in a systematic way by comparing mutant bacteria (Liu et al., 2015), lacking one or more immune agonists, with their wild type counterpart.

It was found that immune modulation by killed bacteria promoted bone tissue formation following ectopic implantation. This was a significant finding, since it is often presumed that periosteum-derived cells are essential for inflammation-induced new bone formation in the long bones (Alexander et al., 2017; Lin et al., 2014). The observations in the ectopic location furthermore indicated that pro-osteogenic effects of killed bacteria cannot be attributed to the specific immune reaction mediated by boneresiding osteoblasts or osteocytes in response to bacteria (Gasper et al., 2002; Yang et al., 2018). The ectopic location lacks the osteogenic and osteoinductive stimuli that are normally present in bone (Albrektsson and Johansson, 2001). Despite the limited osteoinductivity of the BCP here (Yuan et al., 2006), the incorporation of bacterial stimuli was not able to induce a significant amount of new bone formation in the intramuscular model (Yuan et al., 2006). We therefore also studied the bacterial stimuli together with a minimal dose of exogenous BMP-2 to initiate MSC differentiation (Song et al., 2013). Accordingly, it was found that killed bacteria significantly potentiated the bone formation in these constructs. This confirmed previous findings showing that pro-inflammatory cytokines, including TNF- $\alpha$ and IL-17, act in synergy with osteoinductive signals to enhance the osteogenic differentiation of MSCs both in vitro and in vivo (Croes et al., 2015; Croes et al., 2017b; Croes et al., 2018). These results suggested that bacteria-derived pro-inflammatory stimuli could show therapeutic effects in functional critical-size bone defect models in conjunction with naturally present bone-stimulating cytokines/growth factors and bone-forming cells, independent of exogenous growth factors. The specific interaction between pro-inflammatory stimuli and BMPs needs further investigation, since this could lead to a higher efficacy in the clinical use of BMPs (Epstein, 2013). BMP-2 is the most potent bone-inductive agent known; however, its current supraphysiological use is associated with potentially severe complications (Ali and Brazil, 2014). In this regard, it is of interest to investigate whether a co-delivery approach can cause a desired shift in the BMP-2 dose-response curve to the left and thus lower the minimal effective concentration for bone healing in a clinically-relevant model.

The pro-osteogenic effects of killed bacteria were dose-dependent. A relatively low concentration of $\gamma$ i bacteria $\left(<10^{7} / \mathrm{mL}\right.$ range $)$ promoted osteoinduction. This effect was reversed when the optimal bacterial dose was exceeded, suggesting that only a mild and/ or short-lived inflammatory milieu is favourable for new bone formation. Fracture healing studies show that a timely resolution of the inflammatory response usually leads to the most optimal healing (Claes et al., 2012; Schmidt-Bleek et al., 2015). After bone injury, acute inflammation normally only persists for several days, after which anti-inflammatory cytokines and molecules are upregulated (SchmidtBleek et al., 2015). When inflammation persists, overexpression of pro-inflammatory cytokines can have a negative impact on the osteogenic and angiogenic response (Mountziaris et al., 2011; Schmidt-Bleek et al., 2015). Indeed, reduced bone formation is associated with high $\mathrm{T}$ cell numbers as a sign of exaggerated inflammation (Croes et al., $2017 b$ ). Depending on the context, multiple T cell subsets display different functions in osteogenesis. Gamma delta $\mathrm{T}$ cells are innate-like lymphocytes that contribute to osteogenesis through short-lived expression of IL-17 (Croes et al., 2018; Ono et al., 2016), while memory $T$ cell subsets can induce cell apoptosis and impair osteoblast differentiation by chronic production of IFN- $\gamma$ and TNF- $\alpha$ (Liu et al., 2011; Reinke et al., 2013). Considering the early onset of new bone formation in the tibia model (i.e. $<3 \mathrm{~d}$ ), it is unlikely that humoral responses were involved in the new bone formation induced by $\gamma$ i bacteria. This is furthermore supported by the finding that $\mathrm{T}$ cells are more important than B cells for promotion of bone regeneration (El Khassawna et al., 2017). As a limitation of this study, the immune response at an earlier time point was not determined. It is of interest to evaluate the role of different macrophage subsets in the first days after implantation, since osteogenesis and angiogenesis within bone tissueengineered constructs relies heavily on the activity of these cells (Chen et al., 2016; Davison et al., 2014; $\mathrm{Wu}$ et al., 2013). Moreover, it has been shown that activation of macrophages by bacterial ligands leads to secretion of cytokines stimulating bone formation (Guihard et al., 2012). Considering the shape of the dose-response curves obtained in the current study, it cannot be excluded that the optimal bone-stimulating condition exists for even lower bacterial loads. More elaborate dose-response studies are therefore needed to establish the ideal concentrations, or the minimal threshold concentration of different inactivated bacteria required for a pro-osteogenic response.

To translate the current findings towards potential therapeutic use, it is of importance to establish how bacterial stimuli, or their simplified analogues, affect bone healing in critical size defect or spinal fusion models, relative to or in addition to currently used bone grafts. Since new bone is formed mainly in the periosteal region in the tibia model, osteo-immunomodulatory stimuli may also be readily applied onto fixation devices to accelerate periosteum-dependent fracture healing (Zhang et al., 2016). Unlike the current tibia model, detailed measurements are more meaningful in such bone 
defect models, in addition to measurements of the mechanical performance. As part of aforementioned studies, isolated bacterial components with bonestimulatory effects and minimal side effects should be identified. Although intracellular components, such as bacterial DNA, may contribute to immune activation following bacterial internalisation, immuno-stimulation by $\gamma \mathrm{i}$ bacteria is thought to be largely mediated by bacterial cell wall components (Akira et al., 2006). In line, the novel pro-osteogenic effect found for LTA provides evidence that not only killed bacteria as a whole, but also selective bacterial cell wall components including TLR agonists can be harnessed to modulate the osteogenic response. This is supported by the finding that other TLR ligands can also directly activate pathways involved in osteogenesis in MSCs (Croes et al., 2015; Hwa Cho et al., 2006), or indirectly through induction of proosteogenic cytokines (Guihard et al., 2012). With this purpose in mind, the field of musculoskeletal tissue regeneration could benefit from the advancements made in the research and development of vaccine adjuvants or cancer immunotherapeutic agents, where a shift has already occurred from the use of killed intact bacteria towards the use of single TLR activators (Engel et al., 2011; Steinhagen et al., 2011). In terms of versatility, specific TLRs can be targeted to establish the desired immune cell recruitment and cytokine responses (Dowling and Mansell, 2016). In terms of safety, the use of TLR ligands as immune modulators also offers the advantage that recombinant protein or small synthetic TLR ligands with increased safety profile have already been developed for clinical use (Dowling and Mansell, 2016).

As a further limitation of this study, the possibility of local or systemic confounding effects due to combining multiple experimental conditions within one animal should be mentioned. This approach leads to reliable data using a minimal number of animals through paired statistical testing. Concerning the ectopic model, it is unlikely that the intramuscular and subcutaneous samples affected each other directly through local-cross over effects, as the intramuscular scaffolds were buried deep in the muscle and separated from the subcutaneous implants by the strong muscle fascia and the superficial fascia. Whereas local or systemic interference cannot be completely ruled out, they do not mask the activity of the differentlyloaded ectopic scaffolds. In the current study, the bone volume in the ectopic induction model was consistent with previous studies (Croes et al., 2018), and there were apparent dose-dependent effects of the different immune agonists. Moreover, previous comparative studies in the ectopic location allowed us to identify immune-modulatory factors with opposite effects on ectopic bone formation (i.e. TNF- $\alpha$ and lipopolysaccharide) (Croes et al., $2017 b)$, which correlates with their respective actions in fracture healing studies (Chan et al.,
2015; Reikeras et al., 2005). To further mitigate the chance of systemic interference, ectopic conditions were only investigated in animals without active infection. In these animals, it was found that systemic inflammation had restored to baseline by day 7 following treatment with various doses/species of $\gamma \mathrm{i}$ bacteria, which is comparable to sham-treated rabbits (Croes et al., 2017a). Since promising bacterial stimuli and their doses have now been identified, the findings should be further strengthened in more relevant functional models.

In conclusion, the data presented here show that inflammatory signals can stimulate bone formation in a controlled manner when non-viable bacterial agonists are used. In the ectopic bone induction model, an enhanced osteogenic response in advanced ceramic scaffolds was demonstrated, which paves the way to improve such bone graft substitutes. Since bacterial immune agonists largely act through TLRs to induce innate immune responses, isolated TLR ligands could be more applicable enhancers of bone formation.

\section{Acknowledgements}

The Anna Foundation provided financial support for this study. Dr. J. Alblas is supported by the Dutch Arthritis Foundation. This study was powered by Health Holland, top sector Life Sciences \& Health (grant number TTT1403B). Escherichia coli and Bacillus cereus were provided by Dr. Willem van Schaik (Medical Microbiology, UMC Utrecht). Mycobacterium marinum was obtained from Dr. Edith Houben (Molecular Microbiology, VU Amsterdam). The authors acknowledge James Groot for his assistance during bacterial culture, and Dr. Kok van Kessel (both Medical Microbiology, UMC Utrecht) for his help with the bacterial irradiation.

\section{References}

Akira S, Uematsu S, Takeuchi O (2006) Pathogen recognition and innate immunity. Cell 124: 783-801.

Albrektsson T, Johansson C (2001) Osteoinduction, osteoconduction and osseointegration. Eur Spine J 10 Suppl 2: S96-101.

Alexander KA, Raggatt LJ, Millard S, Batoon L, Chiu-Ku Wu A, Chang MK, Hume DA, Pettit AR (2017) Resting and injury-induced inflamed periosteum contain multiple macrophage subsets that are located at sites of bone growth and regeneration. Immunol Cell Biol 95: 7-16.

Ali IH, Brazil DP (2014) Bone morphogenetic proteins and their antagonists: current and emerging clinical uses. Br J Pharmacol 171: 3620-3632.

Bilgili F, Balci HI, Karaytug K, Sariyilmaz K, Atalar AC, Bozdag E, Tuna M, Bilgic B, Gurler N (2015) Can normal fracture healing be achieved when the implant is retained on the basis of infection? An 
experimental animal model. Clin Orthop Relat Res 473: 3190-3196.

Campana V, Milano G, Pagano E, Barba M, Cicione C, Salonna G, Lattanzi W, Logroscino G (2014) Bone substitutes in orthopaedic surgery: from basic science to clinical practice. J Mater Sci Mater Med, 25: 24452461.

Cassat JE, Hammer ND, Campbell JP, Benson MA, Perrien DS, Mrak LN, Smeltzer MS, Torres VJ, Skaar EP (2013) A secreted bacterial protease tailors the Staphylococcus aureus virulence repertoire to modulate bone remodeling during osteomyelitis. Cell Host Microbe 13: 759-772.

Caye-Thomasen P, Tos M (2000) Adaptive bone modeling and remodeling in acute otitis media caused by non-typeable or type B Haemophilus influenzae or Moraxella catarrhalis. Acta Otolaryngol 120: $815-820$.

Chan ED, Morales DV, Welsh CH, McDermott MT, Schwarz MI (2002) Calcium deposition with or without bone formation in the lung. Am J Respir Crit Care Med 165: 1654-1669.

Chan JK, Glass GE, Ersek A, Freidin A, Williams GA, Gowers K, Espirito Santo AI, Jeffery R, Otto WR, Poulsom R, Feldmann M, Rankin SM, Horwood NJ, Nanchahal J (2015) Low-dose TNF augments fracture healing in normal and osteoporotic bone by up-regulating the innate immune response. EMBO Mol Med 7: 547-561.

Chen Z, Klein T, Murray RZ, Crawford R, Chang J, Wu C, Xiao Y (2016) Osteoimmunomodulation for the development of advanced bone biomaterials. Mater Today 19: 304-321.

Claes L, Recknagel S, Ignatius A (2012) Fracture healing under healthy and inflammatory conditions. Nat Rev Rheumatol 8: 133-143.

Croes M, Boot W, Kruyt MC, Weinans H, Pouran B, van der Helm YJM, Gawlitta D, Vogely HC, Alblas J, Dhert WJA, Öner FC (2017a) Inflammation-induced osteogenesis in a rabbit tibia model. Tissue Eng Part C Methods 23: 673-685.

Croes M, Kruyt MC, Groen WM, van Dorenmalen KMA, Dhert WJA, Öner FC, Alblas J (2018) Interleukin 17 enhances bone morphogenetic protein-2-induced ectopic bone formation. Sci Rep 8: 7269.

Croes M, Kruyt MC, Loozen L, Kragten AH, Yuan H, Dhert WJ, Öner FC, Alblas J (2017b) Local induction of inflammation affects bone formation. Eur Cell Mater 33: 211-226.

Croes M, Öner FC, Kruyt MC, Blokhuis TJ, Bastian O, Dhert WJ, Alblas J (2015) Proinflammatory mediators enhance the osteogenesis of human mesenchymal stem cells after lineage commitment. PLoS One 10: e0132781. doi: 10.1371/journal. pone.0132781.

Datta SK, Okamoto S, Hayashi T, Shin SS, Mihajlov I, Fermin A, Guiney DG, Fierer J, Raz E (2006) Vaccination with irradiated Listeria induces protective T cell immunity. Immunity 25: 143-152.

Davison NL, Gamblin AL, Layrolle P, Yuan H, de Bruijn JD, Barrere-de Groot F (2014) Liposomal clodronate inhibition of osteoclastogenesis and osteoinduction by submicrostructured beta-tricalcium phosphate. Biomaterials 35: 5088-5097.

Dowling JK, Mansell A (2016) Toll-like receptors: the swiss army knife of immunity and vaccine development. Clin Transl Immunology 5: e85. doi: 10.1038/cti.2016.22.

El Khassawna T, Serra A, Bucher $\mathrm{CH}$, Petersen A, Schlundt C, Könnecke I, Malhan D, Wendler S, Schell H, Volk HD, Schmidt-Bleek K, Duda GN (2017) T lymphocytes influence the mineralization process of bone. Front Immunol 8: 562.

Elson G, Dunn-Siegrist I, Daubeuf B, Pugin J (2007) Contribution of Toll-like receptors to the innate immune response to Gram-negative and Grampositive bacteria. Blood 109: 1574-1583.

Engel AL, Holt GE, Lu H (2011) The pharmacokinetics of Toll-like receptor agonists and the impact on the immune system. Expert Rev Clin Pharmacol 4: 275-289.

Epstein NE (2013) Complications due to the use of BMP/INFUSE in spine surgery: The evidence continues to mount. Surg Neurol Int 4: S343-352.

Fellah BH, Delorme B, Sohier J, Magne D, Hardouin P, Layrolle P (2010) Macrophage and osteoblast responses to biphasic calcium phosphate microparticles. J Biomed Mater Res A 93: 1588-1595.

Fiedler T, Salamon A, Adam S, Herzmann N, Taubenheim J, Peters K (2013) Impact of bacteria and bacterial components on osteogenic and adipogenic differentiation of adipose-derived mesenchymal stem cells. Exp Cell Res 319: 2883-2892.

Finney SJ, Leaver SK, Evans TW, Burke-Gaffney A (2012) Differences in lipopolysaccharide- and lipoteichoic acid-induced cytokine/chemokine expression. Intensive Care Med 38: 324-332.

Gamblin AL, Brennan MA, Renaud A, Yagita H, Lézot F, Heymann D, Trichet V, Layrolle P (2014) Bone tissue formation with human mesenchymal stem cells and biphasic calcium phosphate ceramics: the local implication of osteoclasts and macrophages. Biomaterials 35: 9660-9667.

Gasper NA, Petty CC, Schrum LW, Marriott I, Bost KL (2002) Bacterium-induced CXCL10 secretion by osteoblasts can be mediated in part through toll-like receptor 4. Infect Immun 70: 4075-4082.

Genêt F, Kulina I, Vaquette C, Torossian F, Millard S, Pettit AR, Sims NA, Anginot A, Guerton B, Winkler IG, Barbier V, Lataillade JJ, Le Bousse-Kerdilès MC, Hutmacher DW, Levesque JP (2015) Neurological heterotopic ossification following spinal cord injury is triggered by macrophage-mediated inflammation in muscle. J Pathol 236: 229-240.

Gerstenfeld LC, Cho TJ, Kon T, Aizawa T, Tsay A, Fitch J, Barnes GL, Graves DT, Einhorn TA (2003) Impaired fracture healing in the absence of TNF-alpha signaling: the role of TNF-alpha in endochondral cartilage resorption. J Bone Miner Res 18: 1584-1592.

Gothard D, Smith EL, Kanczler JM, Rashidi H, Qutachi O, Henstock J, Rotherham M, El Haj A, 
Shakesheff KM, Oreffo RO (2014) Tissue engineered bone using select growth factors: A comprehensive review of animal studies and clinical translation studies in man. Eur Cell Mater 28: 166-207.

Guihard P, Danger Y, Brounais B, David E, Brion R, Delecrin J, Richards CD, Chevalier S, Rédini F, Heymann D, Gascan H, Blanchard F (2012) Induction of osteogenesis in mesenchymal stem cells by activated monocytes/macrophages depends on oncostatin M signaling. Stem Cells 30: 762-772.

Hwa Cho H, Bae YC, Jung JS (2006) Role of toll-like receptors on human adipose-derived stromal cells. Stem Cells 24: 2744-2752.

Kadam A, Millhouse PW, Kepler CK, Radcliff KE, Fehlings MG, Janssen ME, Sasso RC, Benedict JJ, Vaccaro AR (2016) Bone substitutes and expanders in spine surgery: a review of their fusion efficacies. Int J Spine Surg 10: 33.

Kieser KJ, Kagan JC (2017) Multi-receptor detection of individual bacterial products by the innate immune system. Nat Rev Immunol 17: 376-390.

Kim J, Yang J, Park OJ, Kang SS, Kim WS, Kurokawa K, Yun CH, Kim HH, Lee BL, Han SH (2013) Lipoproteins are an important bacterial component responsible for bone destruction through the induction of osteoclast differentiation and activation. J Bone Miner Res 28: 2381-2391.

Kimbrell MR, Warshakoon H, Cromer JR, Malladi S, Hood JD, Balakrishna R, Scholdberg TA, David SA (2008) Comparison of the immunostimulatory and proinflammatory activities of candidate Grampositive endotoxins, lipoteichoic acid, peptidoglycan, and lipopeptides, in murine and human cells. Immunol Lett 118: 132-141.

Lew DP, Waldvogel FA (2004) Osteomyelitis. Lancet 364: 369-379.

Lin Z, Fateh A, Salem DM, Intini G (2014) Periosteum: biology and applications in craniofacial bone regeneration. J Dent Res 93: 109-116.

Liu Q, Li Y, Zhao X, Yang X, Liu Q, Kong Q (2015) Construction of Escherichia coli mutant with decreased endotoxic activity by modifying lipid A structure. Mar Drugs 13: 3388-3406.

Liu Y, Wang L, Kikuiri T, Akiyama K, Chen C, Xu X, Yang R, Chen W, Wang S, Shi S (2011) Mesenchymal stem cell-based tissue regeneration is governed by recipient T lymphocytes via IFN- $\gamma$ and TNF- $\alpha$. Nat Med 17: 1594-1601.

Ma J, Both SK, Yang F, Cui FZ, Pan J, Meijer GJ, Jansen JA, van den Beucken JJ (2014) Concise review: cell-based strategies in bone tissue engineering and regenerative medicine. Stem Cells Transl Med 3: 98107.

Maksymowych WP (2010) Disease modification in ankylosing spondylitis. Nat Rev Rheumatol 6: 75-81.

Marchand LS, Rothberg DL, Kubiak EN, Higgins TF (2017) Is this autograft worth it?: the blood loss and transfusion rates associated with reamer irrigator aspirator bone graft harvest. J Orthop Trauma 31: 205-209.
Marriott I (2013) Apoptosis-associated uncoupling of bone formation and resorption in osteomyelitis. Front Cell Infect Microbiol 3: 101.

Mountziaris PM, Spicer PP, Kasper FK, Mikos AG (2011) Harnessing and modulating inflammation in strategies for bone regeneration. Tissue Eng Part B Rev 17: 393-402.

Nair SP, Meghji S, Wilson M, Reddi K, White P, Henderson B (1996) Bacterially induced bone destruction: mechanisms and misconceptions. Infect Immun 64: 2371-2380.

Odekerken JC, Arts JJ, Surtel DA, Walenkamp GH, Welting TJ (2013) A rabbit osteomyelitis model for the longitudinal assessment of early post-operative implant infections. J Orthop Surg Res 8: 38.

Ono T, Okamoto K, Nakashima T, Nitta T, Hori S, Iwakura Y, Takayanagi H (2016) IL-17-producing $\gamma \delta \mathrm{T}$ cells enhance bone regeneration. Nat Commun 7: 10928.

Pavey GJ, Qureshi AT, Hope DN, Pavlicek RL, Potter BK, Forsberg JA, Davis TA (2015) Bioburden increases heterotopic ossification formation in an established rat model. Clin Orthop Relat Res 473: 2840-2847.

Peterson JR, De La Rosa S, Eboda O, Cilwa KE, Agarwal S, Buchman SR, Cederna PS, Xi C, Morris MD, Herndon DN, Xiao W, Tompkins RG, Krebsbach PH, Wang SC, Levi B (2014) Treatment of heterotopic ossification through remote ATP hydrolysis. Sci Transl Med 6: 255ra132. doi: 10.1126/ scitranslmed.3008810.

Redlich K, Smolen JS (2012) Inflammatory bone loss: pathogenesis and therapeutic intervention. Nat Rev Drug Discov 11: 234-250.

Reikeras O, Shegarfi H, Wang JE, Utvag SE (2005) Lipopolysaccharide impairs fracture healing: an experimental study in rats. Acta Orthop 76: 749-753.

Reinke S, Geissler S, Taylor WR, Schmidt-Bleek K, Juelke K, Schwachmeyer V, Dahne M, Hartwig T, Akyüz L, Meisel C, Unterwalder N, Singh NB, Reinke P, Haas NP, Volk HD, Duda GN (2013) Terminally differentiated CD8(+) T cells negatively affect bone regeneration in humans. Sci Transl Med 5: 177ra136. doi: 10.1126/scitranslmed.3004754.

Rockel C, Hartung T, Hermann C (2011) Different Staphylococcus aureus whole bacteria mutated in putative pro-inflammatory membrane components have similar cytokine inducing activity. Immunobiology 216: 316-321.

Schmidt-Bleek K, Kwee BJ, Mooney DJ, Duda GN (2015) Boon and bane of inflammation in bone tissue regeneration and its link with angiogenesis. Tissue Eng Part B Rev 21: 354-364.

Simmonds MC, Brown JV, Heirs MK, Higgins JP, Mannion RJ, Rodgers MA, Stewart LA (2013) Safety and effectiveness of recombinant human bone morphogenetic protein-2 for spinal fusion: a metaanalysis of individual-participant data. Ann Intern Med 158: 877-889.

Song G, Habibovic P, Bao C, Hu J, van Blitterswijk CA, Yuan H, Chen W, Xu HH (2013) The homing of 
bone marrow MSCs to non-osseous sites for ectopic bone formation induced by osteoinductive calcium phosphate. Biomaterials 34: 2167-2176.

Stadelmann VA, Potapova I, Camenisch K, Nehrbass D, Richards RG, Moriarty TF (2015) In vivo $\mu$ CT monitoring of osteomyelitis in a rat model. Biomed Res Int 2015: 587857.

Steinhagen F, Kinjo T, Bode C, Klinman DM (2011) TLR-based immune adjuvants. Vaccine 29: 3341-3355.

Takeshita S, Fumoto T, Matsuoka K, Park KA, Aburatani H, Kato S, Ito M, Ikeda K (2013) Osteoclastsecreted CTHRC1 in the coupling of bone resorption to formation. J Clin Invest 123: 3914-3924.

Tatara AM, Mikos AG (2016) Tissue engineering in orthopaedics. J Bone Joint Surg Am 98: 1132-1139.

van der Sar AM, Abdallah AM, Sparrius M, Reinders E, Vandenbroucke-Grauls CM, Bitter W (2004) Mycobacterium marinum strains can be divided into two distinct types based on genetic diversity and virulence. Infect Immun 72: 6306-6312.

Wang D, Gilbert JR, Shaw MA, Shakir S, Losee JE, Billiar TR, Cooper GM (2015) Toll-like receptor 4 mediates the regenerative effects of bone grafts for calvarial bone repair. Tissue Eng Part A 21: 1299-1308.

Wu AC, Raggatt LJ, Alexander KA, Pettit AR (2013) Unraveling macrophage contributions to bone repair. Bonekey Rep 2: 373.

Yang D, Wijenayaka AR, Solomon LB, Pederson SM, Findlay DM, Kidd SP, Atkins GJ (2018) Novel insights into Staphylococcus aureus deep bone infections: the involvement of osteocytes. MBio 9: pii: e00415-18. doi: 10.1128/mBio.00415-18.

Yang X, Ricciardi BF, Hernandez-Soria A, Shi Y, Pleshko Camacho N, Bostrom MP (2007) Callus mineralization and maturation are delayed during fracture healing in interleukin-6 knockout mice. Bone 41: 928-936.

Yuan H, van Blitterswijk CA, de Groot K, de Bruijn JD (2006) Cross-species comparison of ectopic bone formation in biphasic calcium phosphate (BCP) and hydroxyapatite (HA) scaffolds. Tissue Eng 12: 16071615.

Zhang Y, Xu J, Ruan YC, Yu MK, O'Laughlin M, Wise H, Chen D, Tian L, Shi D, Wang J, Chen S, Feng JQ, Chow DH, Xie X, Zheng L, Huang L, Huang S, Leung K, Lu N, Zhao L, Li H, Zhao D, Guo X, Chan K, Witte F, Chan HC, Zheng Y, Qin L (2016) Implant-derived magnesium induces local neuronal production of CGRP to improve bone-fracture healing in rats. Nat Med 22: 1160-1169.

\section{Discussion with Reviewer}

Fintan Moriarty: Could the authors speculate on the potential contribution of resident periosteal macrophages (so-called osteomacs) in comparison with recruited macrophages? Additionally, is there any evidence that neutrophils may play a role in the observed response?
Authors: This is an important question. Since the bone deposition occurs predominantly in the (sub)periosteum, one can argue that resident macrophages in the periosteum (i.e. osteomacs) play a role in the osteogenic response in the rabbit tibia model. They may serve an immune surveillance function in bone, as the connective tissue osteomacs, and not osteoblasts, are the main responders to bacterial products in bone explants (Chang et al., 2008). Furthermore, considering the existence of osteomacs and stem cells in the periosteum that are highly responsive to inflammatory signals, it can be speculated that a bone anabolic strategy based on microbial stimuli would be particularly effective in promoting periosteal-mediated bone healing after injury. While this may be true, in the current study we also found that killed bacteria and LTA promoted new bone formation in subcutaneously-implanted scaffolds. This provides evidence that not only boneresident cell sources are critical for inflammationinduced bone formation. Future studies are needed to characterise the contribution of different immune cells subsets. In this respect, the role of neutrophils is increasingly being appreciated. These cells are the first cell type to respond to microbe- and injuryassociated molecular patterns, and several reports have shown that neutrophils initiate downstream responses leading to bone repair (Kovtun et al., 2018). However, in light of recent observations (Bastian et al., 2018), their involvement in osteogenesis is likely mediated through their immune modulatory functions in the very acute phase, rather than a direct regulatory effect on osteoblast differentiation.

Fintan Moriarty: Can the authors speculate as to the nature of the observed within-group variability regarding bone formation in animals treated with the same bacterial species?

Authors: We know from large cohort studies that there is a tremendous amount of inter-individual variation in the response to bacterial, fungal, or viral stimuli ( $\mathrm{Li}$ et al., 2011). Apart from genetic and environmental factors, inter-individual variations in the immune response is established through antigen exposure and innate and adaptive memory development (Netea et al. 2016, Reinke et al. 2013). As a result, even the housing conditions of laboratory mice - i.e. specific pathogen free or not - strongly affects their immune status and bone formation capacity (Reinke et al., 2013). Thus, even though immune variations are reduced in lab animals as compared to humans, the individual animal "immune experience" may in fact be at least one of the variables impacting inflammation-mediated bone formation.

\section{Additional References}

Bastian OW, Croes M, Alblas J, Koenderman L, Leenen LPH, Blokhuis TJ (2018) Neutrophils inhibit synthesis of mineralized extracellular matrix by 
human bone marrow-derived stromal cells in vitro. Front Immunol 9: 945. doi: 10.3389/fimmu.2018.00945.

Chang MK, Raggatt LJ, Alexander KA, Kuliwaba JS, Fazzalari NL, Schroder K, Maylin ER, Ripoll VM, Hume DA, Pettit AR (2008) Osteal tissue macrophages are intercalated throughout human and mouse bone lining tissues and regulate osteoblast function in vitro and in vivo. J Immunol 181: 1232-1244.

Kovtun A, Messerer DAC, Scharffetter-Kochanek K, Huber-Lang M, Ignatius A (2018) J Immunol Res 2018: 8173983. doi: 10.1155/2018/8173983.

Li Y, Oosting M, Smeekens SP, Jaeger M, AguirreGamboa R, Le KTT, Deelen P, Ricano-Ponce I, Schoffelen T, Jansen AFM, Swertz MA, Withoff S, van de Vosse E, van Deuren M, van de Veerdonk F,
Zhernakova A, van der Meer JWM, Xavier RJ, Franke L, Joosten LAB, Wijmenga C, Kumar V, Netea MG (2016) A functional genomics approach to understand variation in cytokine production in humans. Cell 167: 1099-1110.

Netea MG, Joosten LA, Latz E, Mills KH, Natoli G, Stunnenberg HG, O'Neill LA, Xavier RJ (2016) Trained immunity: A program of innate immune memory in health and disease. Science 352: aaf1098. doi: 10.1126/science.aaf1098.

Editor's note: The Scientific Editor responsible for this paper was Fintan Moriarty. 